\title{
PERKAWINAN SOSIO-POLITIS ORANG MELAYU
}

\author{
Muhammad lqbal Anwar \\ E-mail :migbalanwar@gmail.com \\ KUIM Malaysia
}

\begin{abstract}
Islam as a life compass of Malays has become norms and values system and spirit of them. It is because Islam and all of its concept become a compass for Malays in acting and behaving in an interaction to each other including to the women. The interaction has complex meanings, but in this case it concerns to a marriage. The union of a man and a woman is bonded by a marriage. A marriage is a Sunnah and human's desire. It is a physical and spiritual need. The things that would be basis of marriage are parents' aggrement and a strong desire of both brides to build a happy marriage, to live harmonic and ideal together, and also to carry responsibilities either for them or for their descendants as Allah's trusteeship. In building a happy marriage, both sides should know their rights and obligatories, respect, help, and counsel to each each other. They should be able to give and accept and not to be selfish. They should understand and love each other for Allah's Ridha. Each right and obligatory of them has been set by its part in order to avoid problems when facing their life in the future.
\end{abstract}

Keywords: Marriage, Malay, and Islam.

\section{PENDAHULUAN}

Kiprah perempuan yang multi dimensi apakah itu sebagai ibu, pengatur ekonomi, pendidik, satpam dalam rumah tangga atau lain sebagainya selalu marak dibincangkan meskipun pembicaraan itu tetap mengintimidasikan perempuan. Pada hal di pihak lain perempuan telah diakui keberadaan dan kemampuannya termasuk dalam bidang militer dan negara. Pengakuan tersebut telah dirintis jauh sebelum ini yakni lebih kurang empat belas abad nan lalu yang diprakarsai oleh agama Islam. Agama Islam sangat menghormati perempuan bahkan memberikan kesempatan yang luas kepada perempuan untuk mengembangkan diri dan pikiran dalam kehidupan duniawi dan ukhrawi nantinya tanpa mengurangi haknya sebagai anggota masyarakat dan sebagai dirinya sendiri.

Hak perempuan sebagai dirinya sendiri dapat terlihat pada waktu akan dilakukan pernikahan kepada peremppuan dimana untuk menentukan mahar perkawinan berada di tangan perempuan. Perempuanlah yang menentukan mahar yang akan diberikan oleh calon suami kepada dirinya tanpa ada rasa intimidasi atau lain sebagainya karena inilah satu-satunya yang dimiliki oleh 
Al-Fikra: Jurnal IImiah Keislaman, Vol.14, No.2, Juli - Desember 2015

perempuan sebuah hak veto yang tidak boleh diganggu oleh siapapun. Demikian penghormatan agama Islam kepada perempuan sehingga perempuan tidak dianggap sebagai parasit dalam kehidupan rumah tangga yang terdiri dari seorang perempuan dan seorang laki-laki dan perpaduan ini merupakan bagian terkecil dari kelompok masyarakat.

Mahar perkawinanmerupakan hak penuh perempuan artinya apapun yang diminta perempuan kepada calon suaminya sebagai mahar dalam perkawinan, maka pada saat itu seorang laki-laki harus memenuhi permintaan tersebut dan apabila calon suami tidak dapat memenuhi mahar yang diminta oleh perempuan, maka calon suami dibolehkan berhutang yang hukumnya sama berhutang dengan orang lain. Terlepas dari syariat, sebenarnya mahar perkawinan ini merupakan wujud dari niat murni seorang laki-laki kepada seorang perempuan. Selain itu juga merupakan simbol kasih sayang seorang laki-laki kepada seorang perempuan, meskipun kasih saying tidak hanya dilihat dari sebuah mahar perkawinan saja. Kasih sayang dapat diwujudkan dalam bentuk lain, ingat Taj Mahal. Sebuah bangunan megah yang sejarahnya diketahui dunia adalah lambang dari kasih dan sayang Syah Jehan kepada permaisuri yang telah mendahuluinya.

Peristiwa lain tentang kasih sayang antara seorang laki-laki kepada seorang perempuan dapat pula ditinjau sebuah peristiwa bersejarah di tanah Melayu Riau, yakni pulau Penyengat yang sekarang masuk dalam kawasan Provinsi Kepulauan Riau merupakan lambang kasih sayang Sultan Mahmud Syah III (Sultan Kerajaan Riau Lingga) kepada Engku Puteri Raja Hamidah. Pulau Penyengat adalah mahar perkawinan mereka, dengan demikian pulau Penyengat menjadi milik Engku Puteri Raja Hamidah. Menurut tradisi lisan masyarakat yang tersebar di wilayah Melayu Riau, pulau Penyengat disebut pulau emas-kawin atau pulau mahar. Mahar yang diberikan Sultan Mahmud Syah III sultan Riau-Lingga kepada seorang perempuan yang bernama Engku Puteri Raja Hamidah binti Raja Haji Fisabilillah ketika dipersunting menjadi isteri.

Sebelum pulau ini menjadi mahar perkawinan, pada awalnya pulau ini hanya berfungsi sebagai kubu atau benteng yang dipakai Raja Haji Fisabilillah dalam Perang Riau melawan VOC (Belanda). Kondisi pulau ini tidak berpenghuni kecuali ketika terjadi peperangan. Barulah pada awal abad ke-19 pulau Penyengat menjadi tempat tinggal yaitu setelah kepemilikannya diserahkan kepada Engku Puteri sebagai emas kawin yang diberikan Sultan Mahmud Marhum Besar dan akhirnya menjadi tempat kedudukan resmi atau pusat pemerintahan Yang Dipertuan Muda

\footnotetext{
${ }^{1}$ Silakan baca W.G Shellabear, Sejarah Melayu. (Kuala Lumpur : Oxford University Press. 1967).
} 
Engku Puteri Raja Hamidah adalah seorang perempuan yang muncul ke permukaan sejarah sebagai salah seorang pemegang kemudi pemerintahan. Hal ini disebabkan karena dialah pemilik Pulau Penyengat Indera Sakti yang menjadi pusat pemerintahan sebelah Riau dari Kerajaan Riau-Lingga dan daerah takluknya. Selain itu, Engku Puteri adalah pemegang regalia atau alat-alat kebesaran kerajaan Riau-Lingga.

Pulau Penyengat sebagai emas kawin Sultan Mahmud Marhum Besar kepada Engku Puteri merupakan hal yang tidak asing lagi bagi masyarakat Kepulauan Riau. Cerita Lisan yang berkembang di masyarakat tersebut tentunya tidak mungkin dibiarkan begitu saja dan untuk itu dicarilah data-data yang memperkuat keabsahan cerita tersebut sehingga masyarakat sekarang atau generasi muda tidak termanipulasi sejarah yang sangat merugikan bangsa.

Dari peristiwa di atas, banyak hal yang dapat diamati bahkan sangat perlu dilakukan penelitian terhadap kebenaran peristiwa tersebut karena pulau Penyengat Indera Sakti dan peninggalan kerajaan masih dapat ditemui hingga saat ini. Di samping itu, pulau Penyengat dianggap juga pulau keramat oleh sebagian besar masyarakat Riau dan masyarakat Kepulauan sekarang ini. Banyak masyarakat setempat atau dari daerah lain yang berziarah ke makam Engku Puteri dan menyaksikan peninggalan kerajaan Melayu Riau-Lingga yang masih tersimpan dengan baik di pulau itu. Kondisi tersebut tentunya sangat memerlukan perhatian tangan ahli untuk menelaahnya sehingga data sejarah lokal yang ada di daerah tidak hilang begitu saja. Dengan demikian, peristiwa yang pernah terjadi di suatu daerah sangat perlu ditelusuri secara seksama supaya kejelasan peristiwa dapat diketahui secara jelas dan tidak mengada-ada sehingga nantinya generasi muda sebagai pewaris bangsa tidak terbuai dengan cerita-cerita yang tidak masuk akal. Dari analisis sejarah yang akan dilakukan, nantinya akan tergambar kebenaran dan keakuratan data sejarah pulau Penyengat itu dan Engku Puteri sebagai pemiliknya sehingga pelacakan yang dilakukan akan menghasilkan sesuatu yang dapat dipertanggungjawabkan keabsahannya sejarahnya.

\section{Islam dalam dalam Dinasti Melayu}

Sebagaimana yang diketahui secara umum bahwa Islam merupakan risalah terakhir yang diturunkan kepada Muhammad Saw untuk seluruh umat di dunia ini. Dalam ajarannya, Islam tidak hanya mengatur hubungan antara manusia dengan penciptanya saja, akan tetapi juga mengatur hubungan antara manusia dengan manusia lainnya. Aturan itu diramu sedemikian rupa 
Al-Fikra: Jurnal IImiah Keislaman, Vol.14, No.2, Juli - Desember 2015

dan sangat sempurna sekali sehingga umat yang patuh dan taat pada aturan yang dibuat akan menemukan dan mendapatkan kebahagiaan dan kedamaian lahir dan batin..

Demikian juga dengan Melayu, dimana setelah wilayah Melayu dijamah oleh Islam termasuk masyarakatnya, maka pandangan masyarakat Melayu dipengaruhi oleh sistem nilai Islam.Sistem nilai yang demikian mempengaruhi pula kepada pandangan hidup masyarakatnya sehingga muncul sebuah statemen Melayu identik dengan Islam. Sebagaimana yang dikatakan oleh Thamrin (2007:1) bahwa Melayu identik dengan Islam merupakan suatu proses enkulturasi yang mana institusi kemaharajaan Melayu-Islam memainkan peran yang penting dalam proses enkulturasi tersebut. Institusi kemaharajaan Melayu yang menerapkan konstitusi dan sistem nilai Islam telah dapat mengikis sistem tradisi Melayu lama yang animisme dan dinamisme-Hinduisme ke sistem tradisi Melayu Islam.

Salah satu aspek penting yang dibawa Islam adalah konsep yang menghormati perempuan, salah satu dari aplikasinya adalah ketika akan terjadi ikatan perkawinan antara seorang laki-laki dengan seorang perempuan yakni dalam hal pemberian mahar yang akan diberikan calon suami kepadanya artinya skala prioritas ada di tangan perempuan pada saat itu dan apabila calon suami tidak dapat memenuhi mahar yang diminta oleh perempuan, maka calon suami dibolehkan berhutang yang hukumnya sama berhutang dengan orang lain. Artinya pemberian mahar dari seorang laki-laki kepada seorang perempuan merupakan aplikasi dari keberadaan perempuan yang sangat dihomati oleh agama Islam. Penghormatan ini sudah muncul empat belas abad yang lalu ketika perempuan terintimidasi oleh laki-laki di seluruh dunia. Dengan tidak mempersoalkan perhitungan sejarah, masyarakat Melayu telah mengenal agama Islam. Mulai dari abad ke-7 sampai abad ke-15 Masehi, wilayah Melayu diwarnai oleh Islam apakah itu melalui jalur perdagangan, perkawinan atau jalur lainnya. Semua peristiwa tersebut dapat diketahui dari tulisan-tulisan orang dahulu yang pernah menuliskan apa yang diketahuinya. Dan kitapun mengetahui tentang apa yang telah terjadi di masa yang lampau dengan perantaraan pengetahuan yang sampai kepada kita atau dengan pengamatan melalui jejak-jejak sejarah yang telah ditinggalkan manusia.

Masyarakat Melayu yang notabenenya masyarakat yang menganut ajaran Islam secara jelas dipengaruhi oleh sistem nilai Islam dan selanjutnya akan mempengaruhi pula terhadap pandangan hidupnya. Orang Melayu akan mengatakan bahwa agama Islam itu dapat dipakai untuk hidup dan dapat ditumpangi untuk mati. Bermakna bahwa agama Islam dengan segala aspeknya dapat dipakai untuk menyelesaikan persoalan hidup. Keberadaan Islam di wilayah Melayu telah membawa perubahan yang cepat dalam alam pikiran dunia Melayu. Kedatangan Islam adalah revolusi besar dalam kebudayaan Melayu. Kitab suci Al- Qur'an telah menjadi pedoman dasar 
Muhammad lqbal Anwar, Perkawinan Sosio - Politis Orang Melayu

revolusi Islam yang telah memajukan ekonomi, politik, social dan budaya. Sebagaimana yang dikatakan oleh Thamrin (2007:3)bahwa perubahan mendasar yang terjadi di alam Melayu terlihat pada kebudayaan yakni; (1) Islam mengikis kebudayaan kuno; (2) Islam memperbaiki dan menyempurnakan kebudayaan Melayu kuno; (3) Islam menciptakan kebudayaan baru dalam kebudayaan Melayu.

Sistem nilai Islam sangat bersebati dalam kehidupan masyarakat Melayu misalnya dalam pelaksanaan pernikahan di mana seorang perempuan akan menerima sebuah mahar dari sang suami ketika terjadi ijab kabul. Dalam Kamus Besar Bahasa Indonesia (2005 : 696) mahar adalah pemberian wajib berupa uang atau barang dari mempelai laki-laki kepada mempelai perempuan ketika dilangsungkan akad nikah. Mahar dapat juga diartikan dengan maskawin.

Mahar memiliki kekuatan yang luar biasa nilainya bagi perempuan karena mahar yang diterima perempuan merupakan hak milik pribadinya tanpa dapat diganggu gugat oleh siapapun termasuk suami yang memberikan mahar tersebut.Aturan Islam yang berkaitan dengan mahar sangat bersebati bagi masyarakat Melayu. Dengan demikian dalam kehidupan masyarakat Melayu sistem yang dilahirkan oleh ajaran Islam menjadi pedoman hidup dalam keberlangsungan hidup bermasyarakat. Masyarakat Melayu yang hidup di bawah lingkungan yang disebut nusantara, semenjak kedatangan Islam menjadikan ajaran Islam sebagai pedoman dan acuan yang hakiki dalam hidup meskipun terdiri dari berbagai suku dan etnis namun mahar sebagai salah satu syarat perkawinan tetap menjadi hak miliki perempun.

Pada hakikatnya suku yang ada di Indonesia secara umumnya adalah masyarakat yang mempunyai sejarah dan kebudayaan sendiri-sendiri yang berbeda antara satu sama lainnya dan mereka ini menempati satu daerah yang diakui sebagai wilayahnya, yaitu tempat hidup dan sumber kehidupannya. Hal ini bersesuaian dengan pendapat Suparlan (1995:15) yang menyatakan bahwa dalam kehidupan nyata di antara sesama warga dan suku yang hidup di daerahnya masing-masing, kehidupan sukunya merupakan pedoman dan tampak mendominasi corak kehidupan mereka sehari-hari.

Apabila ditinjau jauh ke belakang mengenai keberadaan Indonesia, boleh dikatakan bahwa pada masa pemerintah kolonial dari awal hingga akhir yaitu pada abad ke-17 sampai abad ke-20 nusantara meskipun belum menjadi negara Indonesia seperti sekarang ini sudah merupakan satu kesatuan negara yang didiami oleh suku-suku yang ada pada daerah tersebut, baik dalam bentuk kerajaan-kerajaan maupun dalam bentuk lainnya seperti perkawinan dan hubungan kekerabatan. Di kawasan barat nusantara seperti Sumatera, Kalimantan dan Semenanjung Malaysia masyarakat yang signifikan adalah dominannya ras Melayu dan pengaruh agama Islam 
Al-Fikra: Jurnal IImiah Keislaman, Vol.14, No.2, Juli - Desember 2015

sehingga bahasa Melayu dikatakan sebagai lingua franca pada masanya dan wujudnya aksara Rumi sebagai media pengungkapan tulisan. Inilah yang menyebabkan komunikasi dan informasi di antara kerajaan-kerajaan dan masyarakat Melayu sangat terbuka dan pengaruhnya sangat tinggi.

Situasi yang sama di kalangan kerajaan-kerajaan Melayu yaitu di dalam hal perdagangan rempah-rempah, khususnya lada dan hasil tambang sehingga mengakibatkan muncul persaingan satu sama lain. Persaingan ini dimanfatkan oleh V. O. C untuk menghasud kerajaan yang berada di bawah naungan kerajaan Melayu. Seterusnya Selat Melaka dan Laut Cina Selatan dimeriahkan pula dengan kedatangan suku Bugis dari Sulawesi yang diusir dari daerahnya akibat campur tangan V. O. C di daerah itu. Kekuatan Bugis ini memberi corak tersendiri di daerah Melayu sehingga memperkayakan kebudayaan dan sejarah kerajaan Melayu itu sendiri. Oleh itu, wajar dan sangat tepatkira apabila dilakukan penggalian kembali terhadap peristiwa-peristiwa sejarah terdahulu yang berasal dari kerajaankerajaan yang berjaya pada masanya karena mengenang kembali masa lampau berarti mengungkap kembali sejarah daerah-daerah yang tersebar di daerah Melayu.

Di Riau, sebahagian besar masyarakatnya adalah suku Melayu. Suku Melayu yang dimaksudkan jauh sebelum kemerdekaan Indonesia sudah berkembang sejak semula. Untuk mengelak salah paham, lebih dahulu akan dijelaskan bahwa suku Melayu yang disebutkan sebelum ini disebut juga dengan istilah orang Melayu.

Dalam pembahasan kebahasaan, pengertian Melayu meliputi penduduk yang mendiami kepulauan Indonesia, tanah semenanjung sampai kepada penduduk di Kepulauan Polinesia. Mereka ini mempunyai kesamaan dalam bahasa dan budaya. Oleh karena itu, mereka disebut sebagai bangsa Melayu-Polinesia. Istilah tersebut juga dipakai oleh Humboldt, yang kemudian oleh Schmidt diganti istilah itu dengan bangsa Austronesia yang pada dasarnya tidak jauh berbeda dengan istilah sebelumnya. ${ }^{5}$ Secara geografis, negeri Melayu menurut Hamka bermula dari semenanjung Malaysia terus ke Sumatera, Jawa, Kalimantan, Sulawesi dan pulau-pulau Nusa Tenggara serta pulau-pulau Maluku termasuk Irian dan terus ke Pulau Luzon dan Mindanao. ${ }^{6}$ Selain itu, ada beberapa pendapat lain mengenai negeri Melayu seperti Hasyim ${ }^{7}$ dan Hussein, ${ }^{8}$ dan Deraman. ${ }^{9}$ Kemudian dalam

\footnotetext{
5 U.U. Hamidi, 1999, hal. 23.

6 Hamka, 1981, hal. 13.

${ }^{7}$ Muhammad. Yusoff Hashim, Pensejarahan Melayu : Kajian tentang Tradisi Sejarah Melayu Nusantara, 1992, Kuala Lumpur, Dewan Bahasa dan Pustaka, hal. 3 dinyatakan konteks Melayu merujuk kepada dua lapangan iaitu geografi dan bahasa. Dari segi geografi, Melayu menyangkut soal tetnik iaitu semua kelompok kesukuan masyarakat yang mendiami kawasan yang menganjur dari selatan Siam hingga seluruh Malaysia sekarang ini. Seterusnya ke seluruh kawasan Indonesia sekarang yang suatu masa dulu dikenali sebagai
} 
perkembangan yang terjadi melalui sejarah yang panjang, dapat dikatakan bahwa masyarakat atau penduduk yang mendiami selat Melaka, pantai timur Sumatera dan Semenanjung Malaysia memperlihatkan dirinya dengan sesebuah corak budaya yang sangat banyak dicoraki oleh agama mereka iaitu agama Islam. Menurut Hamidi (1999:169), penduduk daerah ini mempunyai tiga identitas : (1) beragama Islam; (2) berbahasa Melayu; (3) mempunyai kesamaan dalam adat dan tradisi.

Untuk menggali sejarah sesebuah kerajaan yang tumbuh dan berkembang di tanah Melayu haruslah digali pula masa lampau masyarakat Melayu tersebut sebagai pelaku sejarah kerajaan, karena menggali sejarah sama dengan meneroka kembali rekod masa lampau yang pernah terjadi pada masyarakat. Sejarah selalu dihubungkan dengan manusia terutama dalam hubungan perebutan kekuasaan sehingga harus dipahami sejarah kekuasaan. Siapa yang memerintah pada satu masa, atau bagaimana pemerintahannya. Karena itu, yang lebih banyak disinggung adalah golongan atasan sahaja. Sebagaimana pandangan Umar Junus (1989: xiv), dengan sejarah kita seakan dibawa kepada peristiwa demi peristiwa yang tentunya berhubungan dengan kekuasaan. Peristiwa-peristiwa itu dianggap sebagai peristiwa kongkrit dan buktinya tentu saja berhubungan dengan perebutan kekuasan yang mesti dilengkapi dengan tarikh yang agak pasti tentang masa berlaku sesuatu peristiwa. Dengan begitu, apabila kita dapat memberikan tarikh yang pasti tentang suatu peristiwa meskipun dalam bentuk abad, maka kebenaran sejarah seakan tidak perlu diragukan lagi. Dan apabila tarikh itu tidak dapat dinyatakan kadangkala kita dapat meyakinkan orang dengan berkata: "sayang tahunnya yang pasti belum dapat diberikan". Pada perkara ini, taktik ini digunakan ketika menentukan tahun kepemilikan pulau Penyengat bagi Engku Puteri Raja Hamidah.

Sejarah berasal daripada kata Arab syajarah yang bererti pohon yang merujuk kepada asal-usul sesuatu bangsa. Orang Jerman menyebutnya geschichte manakala orang Inggris menyebutnya history yang berasal dari kata Yunani istoria. Istoria bererti ilmu untuk semua macam ilmu pengetahuan tentang gejala alam, entah yang disusun secara kronologis

nusantara, sebahagian daripada Filipina Selatan, termasuklah Kepulauan Sulu dan Brunai Darussalam.

8 Harun Mat Piah, "Tamadun Melayu Sebagai Asas Kebudayaan Kebangsaan, Suatu Tinjauan dan Justifikasi" dalam Ismail Hussein (penyelenggara), Tamadun Melayu, 1989, Jilid Dua, Kuala Lumpur, Dewan Bahasa dan Pustaka, hal. 431 mengatakan dari perspektif geografi, bumi Melayu merangkumi daerah yang cukup luas iaitu Taiwan dan Sri Langka di utara, Kepulauan Indonesia di selatan, Madagaskar di barat dan Irian Jaya di timur.

${ }^{9}$ A. Azis Deraman, Masyarakat dan Kebudayaan Malaysia, edisi baharu, 2003, hal. 11 dikatakan bahwa daerah kebudayaan Melayu adalah Kepulauan Melayu meliputi Malaysia, Indonesia, Filipina, Singapura, dan seluruh pulau di sekitarnya dan Asia Tenggara, termasuk bahagian selatan China, Yunan, Burma, Malagasi, Formosa, selatan Siam, Kemboja, Vietnam dan Laos. 
Al-Fikra: Jurnal IImiah Keislaman, Vol.14, No.2, Juli - Desember 2015

mahupun yang berhubung kait dengan manusia. Gottchalk (1985:30) menyebutkan bahwa sejarah adalah bahagian daripada masa lampau manusia yang dapat disusun kembali secara berarti berdasarkan rakamanrakaman yang ada dan juga berdasarkan kesimpulan-kesimpulan mengenai lingkungannya. Sedangkan Gazalba (1981:2) menyebutkan bahwa pengertian sejarah adalah sesuatu yang telah berlalu, sesuatu peristiwa, sesuatu kejadian pada masyarakat masa lalu. Begitu juga Abdulgani (1981:5) menyebutkan bahwa sejarah adalah sesuatu bidang ilmu yang mengkaji secara sistematis keseluruhan perkembangan masyarakat serta kemanusiaan di masa lampau beserta segala kejadian-kejadian dengan maksud menilai secara kritis seluruh hasil kajian tersebut dan pada akhirnya dijadikan perbendaharaan pengetahuan, pedoman penilaian, penentuan keadaan sekarang serta arah proses masa depan.

Berdasarkan pembentangan beberapa pengertian di atas, maka boleh dikatakan bahwa sejarah adalah ilmu yang mempelajari susunan kejadian yang telah dilakukan manusia yang bertindak sebagai pelaku sejarah yang menyangkut keseluruhan perubahan, perkembangan masyarakat dan kemanusiaan secara automatis mengalami perkembangan dan kemajuan. Sebagaimana yang diungkapkan oleh Gottchalk (1975:4) bahwa yang disebut sejarah adalah bagian dari pada masa lampau manusia yang dapat disusun kembali secara berarti berdasarkan rekaman-rekaman yang ada dan berdasarkan kesimpulan-kesimpulan mengenai lingkungannya. Di samping itu, dari beberapa teori sejarah yang telah dikemukakan di atas, maka teori sejarah tersebut akan boleh diketahui dan teruji kebenarannya berdasarkan peninggalannya.

Menurut Abdullah (2001:3-6) pada hakikatnya pengertian sejarah dapat bermakna ganda, makna pertama yaitu sejarah sebagaimana peristiwa tertentu yang terjadi pada masa lalu. Orang Perancis menyebutnya historierealite. Manakala makna kedua, yaitu sejarah sebagaimana peristiwa yang dikisahkan atau ditulis dan disebut juga dengan historie-recite. Kalau yang pertama peristiwanya telah terjadi dan tidak bisa diulang lagi manakala yang kedua adalah usaha sejarawan atau pengkisah untuk merekonstruksi peristiwa yang telah berlalu itu ke dalam kisah sejarah atau narative history atau bisa juga bersifat analytical history dengan menggunakan sumbersumber sejarah, baik sumber primer mahupun sumber sekunder. Di samping itu, history-recite bersifat selektif karena tidak semua peristiwa masa lalu yang akan dikisahkan boleh dikatakan sebagai sebuah sejarah. Selain itu, sejarah adalah masalah "pilihan" dengan kata lain, dalam merekonstruksi masa lalu ada hal-hal yang menentukan pilihan itu. Landasan pertama adalah masalah apa yang menjadi perhatian utama. Perkara ini wajar karena sejarawan boleh menentukan pilihannya untuk merekonstruksi peristiwa mengenai hal-hal yang berhubungkait dengan period, negeri, tema apakah politik, ekonomi, sosial atau budaya. Landasan berikutnya adalah masalah 
Muhammad lqbal Anwar, Perkawinan Sosio - Politis Orang Melayu

penggunaan data atau pilihan yang akan dijadikan 'fakta sejarah' dan 'hirarki fakta' dalam rekonstruksi. Semua itu merupakan kajian mendasar dalam ilmu sejarah sebagai sesebuah usaha akademis yang bersifat kritis dalam merekonstruksi peristiwa masa lalu.

Gottschalk (1975:41) menegaskan bahwa dalam mengungkapkan sejarah sekurang-kurangnya empat pertanyaan boleh diajukan iaitu (1) pertanyaan bersifat geografis; (2) pertanyaan bersifat biografis; (3) pertanyan bersifat kronologis; (4) pertanyaan bersifat fungsional atau okupasionil. Dengan jawaban dari empat pertanyaan tersebut akan diperoleh sebuah gambaran peristiwa yang terjadi pada masa dahulu sehingga peristiwa tersebut dapat direkonstruksi kembali berdasarkan peninggalan-peninggalan yang dikatakan sebagai sumber, baik sebagai sumber primer mahupun sebagai sumber sekunder. Kemudian dalam menuliskan sejarah yang berhubungkait sesuatu tempat, periode, peristiwa, lembaga atau orang, juga bertumpu kepada empat kegiatan pokok iaitu ; (1) pengumpulan objek yang berasal dari zaman itu dan pengumpulan bahan-bahan tercetak, tertulis dan lisan yang boleh jadi relevan; (2) menyingkirkan bahan-bahan atau bahagian yang tidak otentik; (3) menyimpulkan kesaksian yang dapat dipercaya mengenai bahan-bahan yang otentik; (4) penyusunan kesaksian yang dapat dipercaya itu menjadi sesuatu kisah atau penyajian yang berarti.Carr (1988:13-19) menganalogikan sejarah sebagai sesebuah permainan (puzzle) di mana sejarawan harus bisa mencari, menemukan, dan memasukkan pilihannya (fakta) dalam konteks yang benar yang sesuai dengan kenyataan yang ada. Dokumen merupakan bahagian dari fakta, dokumen adalah barang mati dan merupakan peninggalan masyarakat masa lalu yang sangat bererti. Lebih lanjut Carr menegaskan bahwa seorang sejarawan harus bisa menghidupkan fakta-fakta tersebut dengan cara menganalisis melalui penelusuran interpretasi sehingga fakta dan dokumen yang dijumpainya dapat berdialog dan hidup. Bermakna seorang sejarawan bertindak menghidupkan dokumen sehingga dapat mengungkapkan sesuatu kepada orang lain.

Selanjutnya, semua peristiwa dapat diketahui dari tulisan-tulisan orang dahulu yang pernah menuliskan apa yang diketahuinya. Dan kitapun mengetahui tentang apa yang telah terjadi di masa yang lampau dengan perantaraan pengetahuan yang sampai kepada kita atau dengan pengamatan melalui jejak-jejak sejarah yang telah ditinggalkan manusia. Peristiwa yang telah lampau yang dialami manusia, apalagi yang telah terjadi beratus-ratus tahun berselang hanya dapat diketahui orang melalui bekasbekas, peninggalan-peninggalan dan pembuktian-pembuktian dari adanya peristiwa itu dengan lain perkataan jejak-jejak sejarah yang sampai kepadanya. Jika pembuktiannya, baik yang berupa lisan dari mulut ke mulut maupun berupa tulisan itu tidak sampai kepada orang, maka mustahillah dapat diketahui bahwa peristiwa itu telah pernah terjadi di masa yang lalu. 
Al-Fikra: Jurnal IImiah Keislaman, Vol.14, No.2, Juli - Desember 2015

Makin banyak bekas-bekas atau jejak-jejak dari masa yang lampau itu makin sempurnalah rekonstruksi kita tentang masa yang silam itu.

Namun kesulitan yang terjadi adalah disebabkan pembuktianpembuktian itu kebanyakan tidak sampai ke tangan kita karena disembunyikan orang atau hancur karena peperangan atau hilang karena pencurian, atau akibat bencana alam atau tidak diketahui di mana beradanya ataupun tidak dicatat orang. Menyadari bahwa masih banyaknya sumbersumber sejarah di Indonesia yang belum diselidiki oleh para ahli menyebabkan penulisan sejarah nasional Indonesia belum dapat dikatakan sempurna, karena itu sungguh dirasa perlu sebagai suatu kewajiban terutama bagi ilmuwan bidang sejarah untuk menggali sumber-sumber sejarah terutama sumber sejarah yang berada di daerah-daerah yang selama ini sukar dicapai karena kekurangan komunikasi, informasi dan lain sebagainya.

Dikarenakan salah satu sasaran pembangunan nasional yang dilaksanakan adalah pembinaan budaya dan penggalian sejarah daerah dalam rangka memperkaya kebudayaan nasional, maka penggaliaan sejarah daerah adalah dijadikan salah satu sumber maupun bagian terpenting dari sejarah nasional karena sejarah nasional merupakan sejarah bangsa Indonesia. Oleh karena itu, sangat tepat kiranya apabila dilakukan penggalian kembali peristiwa-peristiwa sejarah terdahulu yang berasal dari kerajaan yang pernah jaya pada masanya karena mengenang dan menggali masa lampau berarti kita berhasil mengungkapkan kembali sejarah daerah yang tersebar di nusantara ini. Sebagaimana yang dikatakan oleh Taufik Abdullah (1983:6 ) bahwa penelitian yang menyangkut suatu desa atau suatu wilayah yang mencakup berbagai desa atau bahkan yang lebih besar lagi seperti sebuah komunitas suku, maka itu dikatakan sejarah lokal. Apabila diperhatikan pada permasalahan yang terdapat pada penelitian ini, maka dapatlah dikatakan bahwa penelitian ini merupakan penelitian sejarah lokal karena yang diteliti adalah peristiwa yang terjadi di suatu wilayah yakni Melayu. Yang dijadikan sasaran utama dari penelitian sejarah local ialah suatu komunitas dalam suatu daerah geografis tertentu yang batas-batasnya ditentukan berdasarkan pertimbangan ilmiah si peneliti

Setiap daerah kaya dengan sumber sejarah dan sangat memerlukan tangan-tangan trampil dalam upaya menggali potensi daerah sebut saja pulau Penyengat, sebuah pulau yang disebut pulau mahar penuh dengan peninggalan-peninggalan sejarah masa lalu karena daerah ini merupakan pusat pemerintshan kerajaan yang letaknya sangat strategis secara geografis. Untuk itu, peristiwa sejarah yang diyakini masyarakat hingga saat merupakan peristiwa yang sangat perlu ditinjau keabsahan datanya dengan melakukan penelitian artinya sebagai sebuah penyelidikan yang seksama, teliti terhadap suatu subyek untuk menemukan fakta-fakta guna 
Muhammad lqbal Anwar, Perkawinan Sosio - Politis Orang Melayu

menghasilkan produk baru, memecahkan suatu masalah atau untuk menyokong atu menolak suatu teori.

\section{Riau-Lingga : Perspektif Sosio Historis}

Dalam abad ke-16 dan 17 ada dua kekuasaan di Nusantara yang berpengaruh di Riau yakni pada abad ke-16 sampai pertengahan pertama abad ke-17 adalah Aceh, dan sejak pertengahan abad ke-17 sampai abad ke-18 adalah Bugis. Peperangan atau persekutuan dengan Aceh terlalu banyak untuk disebut satu persatu. Sedangkan campur tangan Bugis pertama terjadi pada tahun 1679 atas undangan Sultan Ibrahim yang diusir dari Johor dan lari ke Riau. Sejak itu sejarah Riau dan sekitarnya terikat dengan kekuatan Bugis yang muncul dengan pesat di perairan Melaka. Khususnya dominasi kekuatan Bugis ini terlihat dari krisis monarkhi Melayu (Johor) ketika rajanya Sultan Mahmud Syah II pengganti Sultan Ibrahim dibunuh dalam tahun 1699 oleh Megat Sri Rama ${ }^{10}$ lalu diganti oleh dinasti Bendahara yakni Sultan Abdul Jalil Riayat Syah IV. Namun, belum berapa lama Sultan Abdul Jalil Riayat Syah IV dari keluarga Bendahara mengendalikan kerajaan Johor, maka tanpa diduga datang serangan dari Raja Kecik mengatasnamakan putera Sultan Mahmud Syah II dari keluarga Melaka Johor untuk merebut tahta Johor yang diperintahnya dari Riau.

Hanya empat tahun memegang tahta Kesultanan Johor, akhirnya Raja Kecik digulingkan oleh Bugis pada tahun 1722 yang menempatkan anak Bendahara Johor sebagai sultan. Bendahara adalah yang mengkhianati dan membunuh Sultan Mahmud Syah II yang merupakan sultan terakhir dari dinasti Melaka-Johor yang berasal dari Parameswari. Dinasti Bendahara ini menjadi dinasti sah dari raja-raja beberapa kesultanan di Sumatera, Semenanjung Melayu dan akhirnya Singapura. Dengan demikian dinasti Kesultanan Riau sebenarnya merupakan cikal bakal raja-raja Melayu dibanyak tempat. Namun, kekuasaan sebenarnya adalah ditangan Bugis dan kemudian Belanda serta Inggris. Menurut Hall (1971) Orang Bugis di perairan Selat Melaka sejak tahun 1722 telah memakai raja-raja Melayu yang sah (keturunan Bendahara) untuk memperkokoh kekuasaan mereka dalam jabatan Raja Muda, Patih, Laksemana dan lain-lain yang merupakan turun temurun kekuasaan yang sebenarnya. Kemudian orang Inggris dan Belanda menggunakan praktik yang sama. Inggris misalnya merebut Singapura dengan mengangkat salah seorang pangeran dari dinasti Riau ini menjadi Sultan Singapura. Untuk memperkuat klaim mereka atas pulau tersebut lalu didirikan pelabuhan imperium Inggris yang terbesar di belahan timur paling tidak di Asia Tenggara. Sebaliknya Belanda mencoba mengalahkan klaim ini dengan mengatakan bahwa hak-hak Sultan Riau lebih tua atas Singapura

\footnotetext{
${ }^{10}$ Winstedt, 1979, hlm. 50-51. Rujuk pula Buyong Adil , 1971, hlm. 84-85.
} 
Al-Fikra: Jurnal IImiah Keislaman, Vol.14, No.2, Juli - Desember 2015

daripada Pangeran Riau ini. Secara legal Belanda mungkin benar namun kekuatan politik mereka lebih kecil dari Inggris sehingga Inggris berhasil tetap bercokol di Singapura. Usaha-usaha Belanda untuk menjadikan pulau Bintan sebagai suatu pelabuhan bebas yang dapat menyaingi kebesaran Singapura menjadi gagal. Pada tahun 1820, Bintan juga gagal menjadi kekuasaan terbesar dibelahan selatan Malaka, meskipun ia merupakan tempat kediaman dinasti yang sah (legitim) dari garis-garis keturunan raja-raja. Dengan demikian dinasti yang memegang tahta dari keturunan Bendahara adalah Sultan Sulaiman Badrul Alamsyah merupakan boneka Bugis.

Pada mulanya Raja Kecik dengan Raja Sulaiman merupakan saudara beripar namun dikarenakan dendam yang berkepanjangan terjadi peperangan antara kedua beripar itu baik di darat maupun di laut hingga ke Kuala Kedah. Karena lamanya berperang, kedua pasukan hampir kehabisan ubat bedil dan pada suatu kesempatan Raja Kecik dapat menewaskan Daeng Perani dengan melancarkan serangan meriam berpeluru batu. Selanjutnya seranganakhir yang dilancarkan oleh Daeng Marewah atau yang dikenali juga dengan gelaran Kelana Jaya Putera mengakibatkan Raja Kecik tiada berdaya dan tiada sanggup meneruskan peperangan. Akhirnya diadakan musyawarah antara Raja Kecik dengan pihak Raja Sulaiman kemudian regalia kebesaran kerajaan Johor beralih tangan dari tangan Raja Kecik berpindah ke tangan Raja Sulaiman putra Sultan Abdul Jalil Riayat Shah IV. Pada peristiwa penyerahan regalia kerajaan Johor dilakukan pula pembahagian wilayah kerajaan. Isi pembahagian sebagai berikut ${ }^{11}$.

1. Kerajaan dibahagi dua. Pulau-pulau Riau, Lingga dan negeri Johor serta Pahang menjadi daerah kekuasaan Raja Sulaiman. Raja Sulaiman ditabalkan menjadi sultan di kawasan itu dengan gelaran Sultan Sulaiman Badrul Alamsyah.

2. Siak dan jajahan yang berada di pulau Sumatera dan pulau-pulau sekitarnya seperti pulau Karimun menjadi daerah kekuasaan Raja Kecik dan Raja Kecik menjadi sultan di kawasan itu.

Setelah selesai bermusyawarah, maka Raja Kecik berangkat dengan semua orang besar dan hulubalang serta pengikutnya yang setia menuju daratan Sumatera. Sedangkan Raja Sulaiman menguasai Lingga dan Johor dan merupakan sultan pertama setelah wilayah Kesultanan Johor dibagi dua. Sultan Sulaiman merupakan Yang Dipertuan Besar Riau yang pertama di Riau-Johor dari keturunan Bendahara. Semenjak kekuasaan ini bermula, kekuasaan sultan telah terbagi dengan Yamtuan Muda dari keturunan Bugis (Daeng Perani, Daeng Marewa, Daeng Menambun, Daeng Celak). Namun

${ }^{11}$ Silakan merujuk kepada tulisan Tamin, 1988, hal. 16. 
pada akhirnya sultan hanya sebagai simbol saja dan kekuasaan sehari-hari dilaksanakan oleh Yamtuan Muda. Keadaan ini mungkin disebabkan oleh kuatnya tekanan Belanda yang kemudian menjadikan sultan sebagai kaki tangan pemerintah Belanda. Lutfi (1977: 587) mengatakan bahwa dalam perjanjian 18 Mai 1905 pasal 1 ayat 1 disebutkan Sri Paduka Tuan Sultan mengaku akan bersetia dan senantiasa kepada Gubernur Hindia Nederland dan wakilnya serta akan menurut dan menjunjung tinggi segala titah perintahnya.

Wilayah kekuasaan sultan Sulaiman Badrul Alamsyah meliputi Riau Kepulauan, pulau-pulau di muara sungai Inderagiri, Semenanjung Melayu, dan Singapura. Namun lama kelamaan wilayah kekuasan dipersempit. Sultan sebagai Yang Dipertuan Besar pindah ke Lingga dengan wilayah kekuasaannya di pulau Lingga dan Yang Dipertuan Muda Riau di Pulau Penyengat saja. Dengan adanya Perjanjian London 1824 kuasa Yang Dipertuan Besar makin terbatas lagi. Akhirnya Bendahara dijadikan Raja Pahang dan Temenggung sebagai Raja Johor. Perjanjian London ini pula yang memisahkan wilayah Semenanjung Malaysia dan Singapura dengan Riau. Sejak itu kesultanan lebih dikenal dengan nama Kesultanan RiauRingga

Selain itu, mengenai kawasan kerajaan ini dapat diacu juga kepada Surat-surat Perjanjian atau Kontrak Politik antara pemerintah kesultanan dengan pemerintah Belanda sebagaimana yang terhimpun dalam arsip ${ }^{12}$ yang masih dapat dilihat sekarang ini. Berdasarkan arsip tersebut dapat disimpulkan bahwa yang dinamakan Kerajaan Riau-Lingga ialah seluruh Provinsi Kepulauan Riau setelah pemekaran daerah ditambah dengan daerah-daerah lain yang berada di Provinsi Riau, seperti Inderagiri yang terdiri dari Inderagiri Hilir dan Inderagiri Hulu.

Nama kerajaan ini selalunya berubah-ubah sesuai dengan tempat pusat kerajaannya berada. Pada mulanya pusat pemerintahan kerajaan ini berada di Tanah Besar Semenanjung di kawasan Johor. Lalu pemerintahan berpusat di Riau yaitu di Sungai Carang Pulau Bintan, sebuah tempat yang pertama kali dibuka oleh Bendahara Paduka Raja Tun Abdul Jamil yang juga berpangkat Laksemana. Beberapakali pusat pemerintahan ini terus berpindah dari Johor ke Riau dan sebaliknya. Baru kemudian menetap di Riau. Mengenai nama kerajaan ini sejalan dengan pusat pemerintahannya berada. Dengan demikian nama kerajaan ini menjadi banyak sebutannya sesuai dengan keberadan pusat pemerintahan yang berjalan. Oleh karena itu, kerajaan ini pernah dinamakan (1) Kerajaan Johor-Riau; (2) Kerajaan

12 Tersimpan dengan rapi di Kantor Arsip Nasional RI Jakarta dengan judul Surat-surat Perjanjian antara Kesultanan Riau dengan Pemerintahan V. O. C dan Hindia-Belanda 17841909. 
Al-Fikra: Jurnal IImiah Keislaman, Vol.14, No.2, Juli - Desember 2015

Riau-Johor. Setelah tahun 1824 dinamakan dengan (3) Kerajaan Riau (tanpa Johor dan Pahang); (4) Kerajaan Lingga-Riau; (5) Kerajaan Riau-Lingga; (6) bahkan dinamakan juga dengan Kerajaan Riau.

Dapat dikatakan bahwa secara resmi Riau Lingga digunakan sebagai nama kerajaan, setelah kerajaan itu berpisah dari kerajaan Johor dan Pahang pada tahun $1824 .{ }^{13} \mathrm{Pada}$ hakekatnya kekuasaan pemerintahan Riau-Lingga dijalankan oleh Deang Marewah dan semenjak itu pengaruh Bugis makin besar sedangkan sultan hanya sebagai lambang saja. Sultan Sulaiman menyadari makin terasanya tekanan dari orang-orang Bugis akhirnya minta bantuan kompeni untuk mengusir orang Bugis tersebut dan Sultan Sulaiman mengadakan perjanjian dengan Belanda. Akibat campur tangan Belanda, maka pertikaian antara Sultan Sulaiman dengan orang Bugis berlangsung berlarut-larut. Namun, pertikaian ini berakhir juga setelah diadakan perdamaian antara Sultan Sulaiman dengan orang Bugis pada tanggal 1 Desember 1759 di mana kedudukan orang Bugis diakui kembali sebagai Yang Dipertuan Muda. Tidak lama setelah perdamaian itu Sultan Sulaiman meninggal dunia pada tahun 1759.

Jika dilihat dari topografis wilayah, kerajaan Riau Lingga dapat dimasukkan sebagai kerajaan maritim. ${ }^{14}$ Oleh karena seluruh wilayah utama dan daerah taklukannya dikelilingi oleh lautan, maka jarak antara satu pulau dengan pulau lainnya dipisahkan oleh selat dan laut. Sungai dipergunakan untuk menghubungkan antara penduduk yang mendiami wilayah pedalaman dengan penduduk di daerah pinggir pantai. Selat dilayari oleh sampan dan kapal yang menjembatani satu kelompok masyarakat dengan kelompok lainnya. Laut merupakan ajang sumber kehidupan utama masyarakat untuk mendapatkan ikan, tipang, kulit penyu, agar-agar laut sedangkan daratan menghasilkan kayu, damar, rotan, atap, dan hasil perkebunan. ${ }^{15}$

Penyebaran penduduk di kerajaan Riau Lingga tidak merata. Kondisi tersebut dapat dimengerti karena sering terjadi perpindahan keluarga dan kelompok masyarakat sesuai dengan peranan dan kepentingan masingmasing. Catatan yang sezaman dengan ini adalah yang dibuat oleh Ranzow pada tahun 1827. la menyebutkan bahwa pulau Bintan, pulau Lingga dan pulau Bungaran berpenduduk sekitar 3. 000 jiwa. Dngan demikian terlihat bahwa penduduk benyak menempati pusat-pusat kerajaan dan terkonsentrasi di perkebunan lada dan gambir. Dicatat juga bahwa penduduk yang terbesar di berbagai tempat berjumlah antara 100 hingga 3.000 jiwa

\footnotetext{
${ }^{13}$ Pernyataan tersebut dapat dibaca dalam tulisan Harry J. Marks, 1959, The First Contest For Singapura 1819-1824, Gravenhage- Martinus Nijhoff.

${ }^{14}$ Lihat Freek Colombijn, "Een Milliu - effect rapportage van de gambircultuur in de Riau artchipel in de negentiende eeuw, " Tijdschrift voor Geschiedenis, 110 (1997), hal. 290-312.

${ }_{15}$ Reinoust Vos, 1993. Gentle J anus, Merchant Prince : The VOC and the tightrope of diplomacy in the Malay world 1740 - 1800, Leiden, KITLV Press.
} 
setiap desa. ${ }^{16}$ Sementara itu pulau Penyengat dan Daik Lingga merupakan tempat kegiatan pemerintahan kerajaan. Sebelum tahun 1824, pusat kegiatan pemerintahan kerajaan terletak di Tanjung Pinang. Setelah pemerintahan Belanda mengambil alih dan memusatkan pemerintahan tidak langsung di Tanjung Pinang pada tahun 1824, tempat itu menjadi pelabuhan yang dikuasai oleh pemerintah Belanda dan berfungsi sebagai entreeport. ${ }^{17}$ Selanjutnya Netscher mengidentifikasikan bahwa penduduk yang mendiami kerajaan Riau Lingga terdiri dari berbagai etnis seperti Melayu, Bugis, Cina, Arab, India, dan bangsa Eropah. Akan tetapi tidak disebutkan jumlah masingmasing pembagian berdasarkan etnis tersebut. ${ }^{18}$

\section{Sultan Mahmud Syah III sultan Riau-Lingga ke-4}

Setelah Sultan Sulaiman wafat pada tahun 1759, dua orang sultan berikutnya yakni Sultan Abdul Jalil dan puteranya Sultan Ahmad dibunuh pada tahun 1761 oleh orang Bugis. Sekalipun peristiwa ini banyak mendapat tantangan dari orang-orang besar Melayu, tetapi orang Bugis tetap bersikeras untuk menunjuk Mahmud (1761-1812) cucu Sultan Sulaiman untuk menduduki tahta kerajaan Melayu meskipun masih berusia satu tahun. Dengan demikian berarti seluruh kekuasaan Melayu sepenuhnya berada di tangan Yang Dipertuan Muda Daeng Kamboja.

Tidak lama setelah itu timbul perselisihan dengan orang Belanda sehingga pelayaran kompeni di Selat Melaka tidak aman bahkan kapal dagang kompeni Belanda di pantai Melaka direbut oleh orang Bugis. Dengan demikian kompeni Belanda mengalami kemunduran sehingga tidak dapat mempertahankan monopoli dagangnya. Kesempatan itu dipergunakan pula oleh pedagang-pedagang Inggrís menyusup ke perairan Selat Melaka.

Dalam bulan Februari 1784 angkatan perang di bawah pimpinan Raja Hají menggempur dan mengepung kota Melaka. Setelah itu bantuan kompeni Belanda dari Batavia datang, maka barulah dapat mengalahkan angkatan perang Raja Hají yang menyebabkan terbunuhnya Raja Hají di Teluk Ketapang pada bulan Juni 1784. Selanjutnya atas kehendak kompeni

\footnotetext{
16 Silakan baca catatan Ranzaow, LC Van, "Korte Geneologi der vorstelijk familie van het rijk van Djohor ... April 1827. "KITLV, Leiden.

17 Pengertian entreeport dari segi bahasa berarti "meletakkan di antara" (to place between), Dari segi ekonomi mengandung arti "a ware house or place for the storage of goods". Tempat ini selanjutnya menjadi "a distributing point for goods, as aseaport or large inland city”.Baca A. Merriem- Webster, 1967, Webster's Seventh New Collegiate Dictionary, Toronto,,Thomas Allen \& Son Limited, hlm. 277. Berdasarkan pengertian di atas, maka entreeport dapat dikatakan sebagai tempat singgah sementara para pedagang yang datang dan pergi dari satu tempat ke tempat lainnya.

${ }_{18}$ Elisa Netsher , 1854, ' Beschrijving van een gedeelte der residentie Riaouw', dalam TBG, II, hlm. 108-270.
} 
Al-Fikra: Jurnal IImiah Keislaman, Vol.14, No.2, Juli - Desember 2015

Belanda, ibukota Keresidenan Belanda ditempatkan di Tanjung Pinang. Pada mulanya Sultan Mahmud Syah III memerintah bersama dengan Orang-orang Besar Kerajaan diawasi oleh seorang Residen Belanda. Residen menghapuskan kerapatan Orang-orang Besar Kerajaan untuk memudahkan bagi kompeni Belanda mengendalikan sultan.

Kemudian terjadi perselisihan faham antara Sutan Mahmud Syah III dengan orang Bugis karena imbalan yang diminta orang Bugis tidak dapat dipenuhi oleh sultan. Sultan Mahmud melarikan diri ke Pahang dan kekuasaan pemerintah berpindah ke tangan Raja Ali keturunan Bugis. Akan tetapi pada awal 1778 kompeni Belanda dapat menguasai Tanjung Pinang kembali. Raja Ali menyerah dan dibuang ke Melaka. Pendudukan kompeni Belanda ini menyebabkan penduduk bangsa Melayu menyingkir dari daerah kekuasaan Belanda sehingga dengan demikian melumpuhkan perdagangan Belanda. Oleh sebab itu, Belanda merasa perlu mengembalikan kedudukan sultan Melayu ke Tanjung Pinang lalu terjadilah perdamaian antara kompeni Belanda dengan Sultan Mahmud Syah III pada tahun 1795 dengan menghasilkan perjanjian.

Akan tetapi, belum sempat perjanjian itu dilaksanakan situasi politik dengan cepat berubah. Seperti diketahui bahwa pada tahun 1789 meletus revolusi Perancis. Paham revolusi tersebut membawa pengaruh yang besar kepada negara-negara Eropah lainya termasuk Belanda. Dengan bantuan tentara revolusi, Belanda mengusir Pangeran Willem $\mathrm{V}$ dari tahtanya. Pangeran Willem V melarikan diri ke Inggris. Negeri Belanda menjadi Bataafse Republik pada tahun 1795. Pemerintah baru Belanda ini bersekutu dengan Perancis. Dengan demikian berarti bahwa Belanda terlibat dalam permusuhan dengan Ingerís karena antara Perancis dan Ingerís telah berlangsung permusuhan atau peperangan yang tidak henti-hentinya bahkan berlangsung di luar batas negeri masing-masing. Untuk mencegah jangan sampai pangkalan-pangkalan Belanda yang ada di Tanjung Harapan, Sri Langka, Melaka, Jawa dan sebagainya dipergunakan oleh Perancis, Inggris mengadakan persetujuan dengan pemerintahan pengasingan Belanda di Inggris. Isi perjanjian itu yang terpenting ialah persetujuan bahwa Inggris akan mengambil alih milik serta pangkalan-pangkalan Belanda tersebut di atas selama peperangan berlangsung.

Atas dasar persetujuan tersebut, maka dalam tahun 1795 Melaka diduduki Ingerís tanpa mendapat rintangan dari Belanda. Setelah itu pangkalan-pangkalan Belanda lainnya segera direbut seperti Riau, dan Maluku. Setelah Inggris menduduki Tanjung Pinang maka Inggris lah yang mengembalikan pengaruh orang Bugis. Kesempatan tersebut dipergunakan pula oleh Raja Ali untuk kembali ke Tanjung Pinang. Raja Ali berhasil menyingkirkan Tengku Muda dari suku Melayu sebagai Yang Dipertuan Muda. Tetapi Sultan Mahmud Syah III tidak mengakuinya dan berusaha terus menerus untuk menyingkirkan Raja Ali ke luar Riau, namun tidak berhasil. 
Muhammad lqbal Anwar, Perkawinan Sosio - Politis Orang Melayu

Akhirnya pada tahun 1803 Sultan Mahmud Syah III terpaksa mengakui Raja Ali dari keturunan Bugis sebagai yang Dipertuan Muda. Untuk menjaga supaya jangan timbul perselisihan dengan Engku Muda, putera Sultan Mahmud Syah III yang tua bernama Tengku Husin (Engku Long) dikawinkan dengan puteri Engku Muda, sedangkan puteranya yang kedua Tengku Abdur Rahman diserahkan dibawah asuhan Raja Ali.

Sebenarnya Sultan Mahmud Syah III tidak merasa senang dengan kembalinya Bugis sebagai Yang Dipertuan Muda. Karena itu ia pindah ke Lingga dan menetap di situ sampai akhir hayatnya dan wafat pada tahun 1812. Pada waktu Sultan Mahmud Syah III baru meninggal dunia, Tengku Husin sedang berada di Pahang bersama Bendahara. Orang Bugis mempergunakan kesempatan ini dan segera menobatkan Tengku Abdur Rahman sebagai sultan. Dengan demikian pengaruh Bugis dapat dipertahankan karena anak yang tidak begitu mempunyai hak akan lebih bergantung kepada bantuan orang Bugis.

Tindakan orang Bugis itu sangat menyakitkan hati Tengku Husin. la menuntut haknya atas tahta kerajaan. Tuntutannya itu mendapat sokongan pula dari isteri Sultan Mahmud Syah III yang berketurunan raja yakni Engku Puteri Raja Hamidah, akan tetapi usaha mereka itu sia-sia belaka. Persoalan ini menambah tajamnya perselisihan antara pemuka-pemuka Melayu dengan pihak Bugis.

Dalam kondisi tersebut, Inggris mendarat di Singapura dan mendirikan pangkalan koloni Inggris karena di pulau itu tidak ada orang Belanda dan pulau itu mempunyai pelabuhan yang sangat strategis. Cara yang ditempuh Raffles dari pihak Inggris untuk mendapatkan pulau itu secara hukum yakni dengan jalan mengakui Tengku Husin sebagai raja kerajaan Melayu Riau. Setelah diadakan perundingan dengan Temenggung ternyata Temenggung menyetujui rencana Raffles tersebut lalu Tengku Husin diculik secara diamdiam dan segera setelah tiba di Singapura diadakanlah upacara penobatan Tengku Husin sebagau Sultan Kerajaan Melayu Riau.bikinan Inggrís. Dengan demikian berarti ada dua raja untuk kerajaan Melayu Riau. Yang pertama, Sultan Abdul Rahman yang diakui Belanda berkedudukan di Lingga dan yang kedua Tengku Husin yang diakui Inggris berkedudukan di Singapura.

Sekalipun Belanda memprotes dengan keras tindakan Raffles, namun Singapura tetap berkembang dengan pesat di bawah Inggris sebagai pusat dagang baru yang mengalahkan koloni Belanda. Pertikaian Inggris dengan Belanda baru dapat diselesaikan pada tahun 1824 melalui Traktat London yang mengandung isi di antaranya :

1. Belanda mengakui Singapura sebagai hak milik Inggris.

2. Belanda dan Inggris menyetujui untuk menghindari perselisihan di masa depan dengan membatasi kepentingan mereka pada daerah yang khusus. 
Al-Fikra: Jurnal IImiah Keislaman, Vol.14, No.2, Juli - Desember 2015

3. Daerah khusus itu dipisahkan oleh garis melalui Selat Melada. Daerah yang terletak di sebelah barat dan selatan garis itu adalah milik Belanda, serta daerah yang terletak ke timur dan ke utara garis itu akan menjadi milik Inggrís. ${ }^{19}$

Dalam melaksanakan perjanjian itu Bengkulu yang semula milik Inggrís diserahkan kepada Belanda dan ditukarkan dengan Melaka yang semula milik Belanda. Akibatnya bagi kerajaan Melayu Riau ialah bahwa daerah dan bangsanya sudah resmi terbagi atas dua bagian yakni (1) Tanah Semenanjung dan Singapura menjadi daerah pengaruh Inggris sedangkan (2) Kepulauan Riau dan Lingga menjadi daerah pengaruh Belanda. Perhatikan gambar berikut ini.

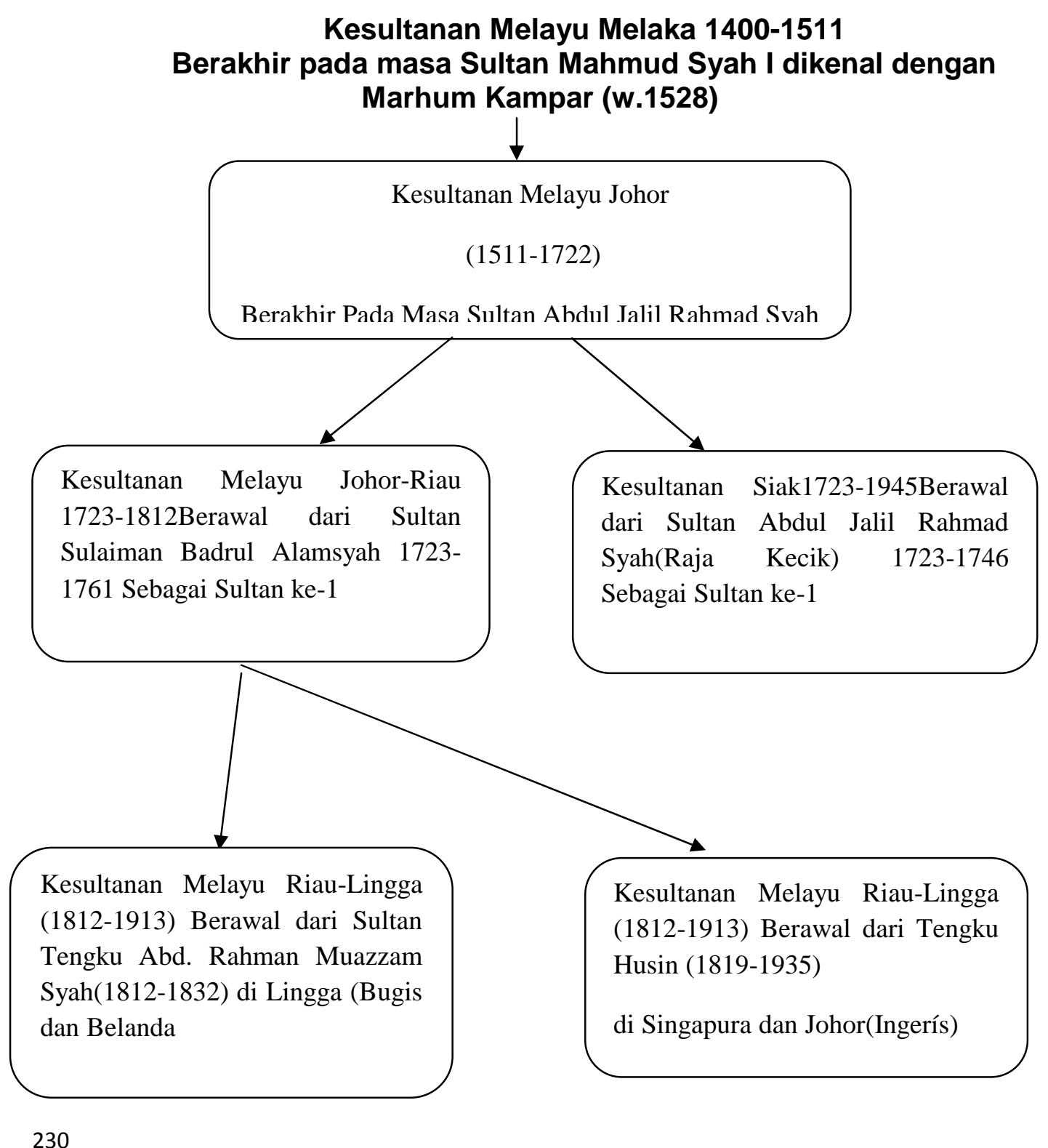


Muhammad lqbal Anwar, Perkawinan Sosio - Politis Orang Melayu

\section{Perkawinan Sultan Mahmud Syah III}

Sultan Mahmud Syah III yang memerintah dari tahun 1761 hingga tahun 1812 adalah sultan kerajaan Riau Lingga yang ke-4. Sultan ini menggantikan Sultan Sulaiman Badrul Alamsyah sultan Johor ke-13, putera dari Sultan Abdul Jalil Riayat Syah IV sultan Johor ke-11 yang berasal dari keturunan Bendahara yang dikalahkan oleh Raja Kecik pada tahun 1718.

Setelah adanya pembagian wilayah, maka Kesultanan Johor terpecah menjadi dua yakni Kerajaan Johor Riau yang dipimpin oleh Sultan Sulaiman Badrul Alamsyah dan Kerajaan Siak yang dipimpin oleh Raja Kecik. Apabila diurutkan dari atas, maka Sultan Mahmud Syah III adalah sultan yang ke-16 dari Kesultanan Johor. Akan tetapi hal itu tentu tidak dapat dikatakan seperti itu, karena Kesultanan Johor sudah terbagi dua yang artinya bahwa Kesultanan Johor sudah berhenti sampai di situ dan diteruskan oleh masingmasing kerajaan yang telah dibentuk dan dipimpin oleh sultannya masingmasing.

Sultan Sulaiman Badrul Alamsyah merupakan sultan pertama kerajaan Melayu Riau-Lingga setelah wilayah kerajaan Johor-Riau dipecah menjadi dua wilayah. Setelah Sultan Sulaiman wafat, baginda digantikan oleh Sultan Abdul Jalil (sultan ke-2) dan Sultan Ahmad (sultan ke-3) yang terbunuh dalam waktu yang tidak jauh berbeda.

Sultan Mahmud Syah III adalah sultan ke-4 kerajaan Melayu Riau Lingga sebagai pengganti Sultan Sulaiman Badrul Alamsyah, selama hidupnya telah melakukan pernikahan berulang kali. Dari perkawinan tersebut ada yang mempunyai keturunan ada pula yang tidak dikaruniai keturunan. Perkawinan lebih dari satu merupakan hal yang diperbolehkan bagi kaum laki-laki karena sudah menjadi aturan yang tertera dalam kitab suci al-Qur'an. Aturan tersebut diiringi dengan syarat yang harus dipenuhi yakni adil. Adil di sini mengandung arti yang tidak sedikit terutama bagi jiwa dan raga isteri yang dinikahi.

Bagi sultan di tanah Melayu, perkawinan lebih dari satu sudah menjadi kebiasaan dengan berbagai alasan dan pertimbangan. Demikian juga dengan Sultan Mahmud Syah III sebagai sultan keempat di kerajaan Melayu RiauLingga juga melakukan perkawinan berulang kali dengan alasan masingmasing.

Berdasarkan data yang diperoleh melalui berbagai sumber yang berhasil dikumpulkan dapat dikatakan bahwa Sultan Mahmud Syah III memiliki isteri sebanyak empat orang yakni : 
Al-Fikra: Jurnal IImiah Keislaman, Vol.14, No.2, Juli - Desember 2015

1. Engku Puan, anak Bendahara Pahang dan merupakan isteri yang gahara. ${ }^{20}$ Perkawinan tersebut tidak membuahkan keturunan.

2. Encik Makoh binti Encik Ja'far Daeng Maturang. Perkawinan tersebut membuahkan keturunan seorang anak laki-laki yang diberi nama Tengku Husin atau Tengku Long atau Tengku Sulung.

3. Encik Maryam binti Datuk Bandar Hasan. Dari perkawinan ini melahirkan Tengku Abdurrahman.

4. Raja Hamidah binti Raja Haji Fisabilillah. Dari perkawinan ini tidak membuahkan keturunan. Raja Hamidah merupakan isteri gahara kedua sehingga dari sinilah gelar Engku Puteri disandangnya sejak perkawinannya pada tahun 1803.

Mengenai perkawinan Sultan Mahmud Syah III menjadi perhatian orang luar bangsa pada masa itu. Seperti halnya Netscher ${ }^{21}$ menulis dalam bukunya yang berjudul De Nederlanders in Djohor en Siak 1602 tot 1865 Historische Beschrijving ${ }^{22}$ sebagai berikut.

12 de J anuarij 1812 overleed Sulthan Mahmoed. Zijne opvolging was de aanleiding tot belangrijke gebeurtenissen in het rijk van Djohor.

Deze vorst was gehuwd met Ongkoe Poewan, eene dochter van den Bandahara van Pahang. Na verloop van eenigen tijd, geene kinderen bij haar hebbende, trouwede hij Intjeh Makoh, eene dochter van eenen Boegies, genaamd Daing Matoerang of Intjeh Djafar. Het huwelijk werd ingezegend door Imam Said, de getuigen er van waren Mohamad Tahir en Lebei Moestafa, met nog vijf andere fat soenlijke lieden. Intjeh Makoh baarde eenen zoon, genaamd Tongkoe Hoesin of Tongkoe Soeloeng.

Eenigen tijd daarna, in 1780, huwde Sulthan Mahmoed Intjeh Mariam, eene dochter van den bandar Hasan. Dit huwelijk was voorgesteld door den

\footnotetext{
${ }^{20}$ Gahara adalah sebuah status quo seorang peremouan yang diperisteri oleh seorang raja atau sultan. Maksudnya, isteri seorang bangsawan apabila tingkatnya sama dengan sang suami. Jika isteri bangsawan itu tidak sederajat dengannya maka si isteri disebut gundik. Pengertian arkais gundik jadi bergeser krpada makna modern. Silakan baca Winstedt dalam A History of Malaya, Kuala Lumpur : Marican \& Sons, 1982, hlm. 159 dituliskan bahwa kedua isteri Sultan Mahmud yang bukan gahara itu sebagai two women of no birth but lawfully wedded sedangkan Raja Hamidah yang oleh banyak sumber dikatakan isteri yang tidak memberikan keturunan kepada Sultan Mahmud Syah III.

${ }^{21}$ Elisa Netscher adalah seorang Belanda yang lama tinggal di Riau. la hidup sezaman dengan Raja Ali Haji. Selama di Riau, ianya bertugas sebagai pejabat di kantor Residen dan bahkan dalam waktu yang cukup lama pernah menjadi Residen Riau. Selain jabatan itu, ia banyak menerjemahkan karya-karya Riau termasuk karya Raja Ali Haji ke dalam Bahasa Belanda. Disamping menerjemahkan buku-buku Riau ke dalam Bahasa Belanda, juga sekaligus menulis tentang situasi dan kondisi Riau pada masanya ia di Riau. Karya Netscher yang berkaitan dengan Riau adalah De Nederlanders in Djohor en Siak 1602 tot 1865 Historische Beschrijving. Buku ini dicetak pada tahun 1870 di Batavia.

${ }^{22}$ Silakan baca pada halaman 403-404.
} 
Muhammad lqbal Anwar, Perkawinan Sosio - Politis Orang Melayu

onderkoning Radja Hadji. Het werd ingezegend te zijnen huize, door Hadji Jakoeb, in tegenwoordigheid van Datoe Soelewatang Ibrahim en den Sabandar Mohamad. Intjeh Mariam baardeen zoon, genaamd Tongkoe Abdu'oerrahman.

Soelthan Mahmoed huwde ten vierde male met Tongkoe Hamidah of Ongkoe Poetri. Eene dochter van wijlwn Radja Hadji, onderkoning van Riouw. Zij bleef kindeloos.

Apabila diterjemahkan ke dalam Bahasa Indonesia mengandung arti sebagai berikut.

Sultan Mahmud meninggal dunia pada tanggal 12 Januari 1812. Penggantian sultan sesudahnya merupakan suatu kejadian yang sangat penting bagi Kerajaan Johor.

Raja ini menikah dengan Engku Puan puteri Bendahara Pahang. Dari perkawinan ini tiada terdapat keturunan lalu beliau menikah pula dengan Encik Makoh, anak seorang Bugis yang bernama Daeng Maturang atau Encik Jafar. Pernikahan dilaksanakan oleh Imam Said dengan saksi-saksi yang terdiri dari Muhammad Tahir dan Lebai Mustafa serta lima orang patutpatut lainnya, Encik Makoh melahirkan seorang putera yang diberi nama Tengku Husin alias Tengku Sulung.

Beberapa waktu sesudah itu, pada tahun 1780 beliau kawin pula dengan Encik Mariam anak Datuk Bandar Hasan, pernikahan tersebut dilaksanakan atas usul Raja Muda Raja Haji. Pentasbihan pernikahan berlangsung di rumahnya oleh Haji Yakub dihadapan Datuk Sulewatang Ibrahim dan Syahbandar Muhammad. Encik Mariam melahirkan seorang anak lelaki yang diberi nama Abdurrahman.

Sultan Mahmud menikah untuk keempat kalinya dengan Tengku Hamidah atau Engku Puteri anak dari Raja Haji yang menjadi Raja Muda pada masa itu. Dari perkawinan ini tidak mendapat keturunan.

Kemudian mengenai keadaan kerajaan dan akhir hayat Sultan Mahmud Syah III juga mendapat perhatian Netscher. Pada hal 405-06 dicatatkan bahwa :

Tijden het overlijden van Sulthan Mahmoed bevon zijn zoon Hoesin zich te Pahang, waar hij eene dochter van den bandahara had getrouwd.

Den dag na het overlijden des Sulthans wer zijn zoon Tongkoe Abd'oerrahman door den onderkoning Radja Djafar verheven tot Sulthan van Djohor. Onder den naam van Sulthan Abd'oerrahman Sjah. Aan deze verheffing ontbrak echter de uittreiking der rijkssieraden, die in handen waren van Sulthan Mahmoeds beide zoons Hoesin en Abd'oerrahman.

Eenigen tijd daarna kwam Tongkoe Hoesin met den bandahara van Pahang te Lingga terug, waar ook de toemenggoeng zich bevon.

Niettegenstaande de rijkssieraden niet door Tongkoe Poetra (lapsus calami: Tongkoe Poetri) werden afgegeven, bleef Sulthan Abd'oerrahman toch de regering voeren. Een Maleisch document, thans nog in het archief 
Al-Fikra: Jurnal IImiah Keislaman, Vol.14, No.2, Juli - Desember 2015

van Sulthans van lingga aanwezig, zegt zelfs, dat en de bandahara en de toemenggoeng Abd'oerrahman als Sulthan erkenden.

Daarmede is in tegenspraak een relaas van Tongkoe Hoesin. In 1827 ingediend aan den Britischen R esident van Singapoera. Wariin wordt gezegd dat Sulthan Mahmoed zijnen zoon Hoesin immer als troonsopvolger zou hebben beschouwd en bij verschillende gelegenheden aan den volke voorgesteld, en dat hij als zoon zou zijn aanngenomen niet aan Sulthan Abd'oerrahman wilde ageven.

Apabila di terjemahkan ke dalam Bahasa Indonesia mengandung arti sebagai berikut.

Ketika Sultan Mahmud wafat, anak beliau Husin sedang berada di Pahang karena ia menikah dengan anak perempuan Bendahara Pahang.

Sehari setelah wafatnya Sultan, Yang Dipertuan Muda Raja Jakfar mengumumkan bahwa Tengku Abdurrahman lah yang diangkat menggantikan ayahanda Sultan Mahmud almarhum dengan gelar Sultan Abdurrahman Syah. Pada penobatan tersebut tidak ada penyerahan regalia kebesaran kerajaan yang berada di tangan Engku Puteri yang merupakan pemegang alat-alat kebesaran kerajaan milik Sultan Mahmud karena menolak untuk menyerahkannya jika tidak ada persetujuan dari Temenggung dan Bendahara Johor beserta kedua putera Sultan Mahmud yaitu Husin dan Abdurrahman.

Beberapa waktu kemudian datang Tengku Husin bersama Bendahara Pahang kembali ke Lingga di mana Temenggung sedang berada. Meskipun regalia kebesaran kerajaan tidak diserahkan oleh Engku Hamidah, Sultan Abdur Rahman tetap menjalankan pemerintahan menjadi pengganti ayahandanya. Menurut satu dokumen Melayu yang tersimpan pada arsip Sultan di Lingga, menyebutkan bahwa baik Bendahara maupun Tumenggung mengakui Sultan Abdurrahman sebagai sultan.

Dalam bantahan yang dibuat oleh Tengku Husin pada tahun 1827 yang disampaikannya kepada Residen Inggris di Singapura dinyatakan bahwa Sultan Mahmud selalu mengingini Tengku Husin yang diangkat menjadi penggantinya dan pada beberapa kesempatan telah diperkenalkan kepada rakyat dan juga telah diambil anak oleh Engku Puteri dan dengan alasan itulah Engku Puteri tidak mau menyerahkan regalia kebesaran kerajaan kepada Sultan Abdur Rahman

Sultan Mahmud Syah III memiliki dua orang anak laki-laki. Satu orang terlahir dari isteri keduanya yang memiliki status bukan gahara dan diberi nama Tengku Husin. Sedangkan satu orang lagi terlahir anak laki-laki dari isteri yang bukan gahara juga yakni isteri ketiga dan diberi nama Tengku Abdur Rahman. Oleh sebab itu, Tengku Husin ialah anak lelaki Sultan Mahmud yang sulung dan Abdur Rahman anak kedua. 
Orang Melayu dalam menetapkan hak-hak atas keturunan raja yang kawin dengan puteri bukan keturunan raja mempunyai perbedaan yang meyakinkan dan juga memperhatikan garis keturunan ibunya. Ayah dari ibu Tengku Abdurrahman ialah seorang pejabat kerajaan dan orang Melayu sedangkan ayah dari Tengku Husin seorang Bugis. Berdasarkan itu jelas bahwa bunda Abdur Rahmanlah yang mempunyai kedudukan dan status yang lebih tinggi.

Tentang pertelingkahan atas tahta kerajaan Riau ini Residen Ruhde menulis surat kepada Gubernur Melaka pada bulan Februari 1786 menyatakan tentang tata cara dan segala aturan pengangkatan seorang raja di negeri Melayu. Keadaan ini menyebabkan pada tahun 1818 Residen Inggris di Melaka William Farquhar datang sehingga terjadi pembelahan kerajaan Johor Pahang Riau Lingga setelah adanya Traktat London tanggal 17 Maret pada tahun 1824 antara Inggris dan Belanda. Daerah di bawah pengaruh Inggris untuk Johor dan Pahang sedangkan Riau Lingga di bawah pengaruh Belanda.

\section{Engku Puteri Raja Hamidah binti Raja Haji Fisabilillah, isteri keempat Sultan Mahmud Syah III}

Engku Puteri Raja Hamidah adalah anak perempuan Raja Haji Fisabilillah dari isterinya yang gahara Riau yaitu Raja Perak binti Yang Dipertuan Muda Riau III Daeng Kamboja. Dari isterinya Raja Perak itu Raja Haji memperoleh dua anak perempuan yaitu Raja Hamidah dan Raja Siti. Raja Hamidah binti Raja Haji Fisabilillah menjadi isteri keempat Sultan Mahmud Syah III. Sultan Mahmud Syah III disebut juga dengan Marhum Besar $^{23}$ Sedangkan Raja Siti menjadi isteri Karaeng Talibak. Dalam hidupnya, Raja Hamidah mempunyai saudara seayah yakni:

(1) Raja Jakfar yang kelak menjadi Yang Dipertuan Muda Riau VI;

(2) Raja Idris yang menjadi Raja Pahang;

(3)Raja Ahmad yang dikenal dengan nama Engku Haji Tua ayah Raja Ali Haji:

(4) Raja Kasim;

(5) Raja Salamah yang kelak menjadi ibu dari Raja Asahan;

(6) Raja Buntit;

(7) Engku Tengah (ibunya anak sultan Inderagiri).

(8) Raja Aminah;

(9) Raja Pasir.

\footnotetext{
${ }^{23}$ Selain disebut dengan Marhum Besar, Sultan Mahmud Syah III dikenal juga dengan gelar Marhum Mesjid karena jenazahnya dimakamkan di mesjid Daik Lingga.
} 
Al-Fikra: Jurnal IImiah Keislaman, Vol.14, No.2, Juli - Desember 2015

Raja Hamidah dilahirkan di pusat kerajaan Riau yang ketika itu bertempat di Kota Lama, Pulau Bintan.Tempat lahir Engku Puteri ini kemudian dikenal dengan nama Ulu Riau atau Riau Lama artinya Riau yang baru berpindah tempatnya dari situ. Pemberian nama seperti itu biasanya ditentukan oleh tempat kedudukan pemegang kemudi pemerintahan pada masa itu seperti Yang Dipertuan Besar atau Sultan dan atau Yang Dipertuan Muda, juga tempat yang jadi pusat pemerintahan, Riau yang baru artinya tempat yang menyandang nama Riau kemudian ialah Penyengat sebagai tempat kedudukan resmi Yang Dipertuan Muda dan Lingga sebagai tempat kedudukan resmi Yang Dipertuan Besar atau Sultan. Dikarenakan Raja Haji mempunyai istana di Kota Piring yaitu di Pulau Biram Dewa ketika memegang jabatan Yang Dipertuan Muda Riau, maka besar sekali kemungkinan Raja Hamidah dilahirkan di istana Kota Piring di Pulau Biram Dewa.

Engku Puteri Raja Hamidah hidup di tengah gemuruh perang yang silih berganti adanya. Perang telah menempanya sehingga dia menjadi seorang tokoh perempuan yang tidak dapat dipandang hanya dari kewanitaannya saja. Raja Hamidah telah biasa mendengar peperangan yang dihadapi oleh ayahandanya Raja Haji. Bahkan telah biasa menyaksikan para inang dan dayang di istana bersibuk tidak tidur semalaman menyiapkan bekal untuk peperangan besok harinya.

Engku Puteri dipandang sebagai pemegang kemudi pemerintahan karena dialah pemilik Pulau Penyengat Indera Sakti yang menjadi pusat pemerintahan sebelah Riau dari Kerajaan Riau-Lingga dan daerah takluknya.. Engku Puteri juga pemegang regalia atau alat-alat kebesaran Kerajaan Riau-Lingga setelah suaminya Sultan Mahmud Syah III wafat. Engku Puteri pemegang regalia bukanlah atas keinginannya pribadi akan tetapi dikarenakan suaminya yang menyerahkan regalia tersebut ke tangannya agar dapat diwariskan kepada yang berhak menerimanya setelah Sultan Mahmud Syah III wafat nanti.

Richard O. Winstedt ${ }^{24}$ menulis tentang Engku Puteri Raja Hamidah sebagai berikut.

... when in 1795 Sultan Mahmud was restored to the throne of his ancestors, fate destined him to be the last Emperor of J ohor, Pahang, the Riau Archipelago, the Carimons and Singapura. Dying in 1812 on Lingga 25 the small island wither he had retreated from Bugis Riau, he left the successions to his throne unsettled, an omission that was to provide the

${ }^{24}$ Silakan baca Richard O. Winstedt dalam tulisannya yang berjudul A History of Malaya, hal. 159.

${ }_{25}$ Tentang kematian sultan, dapat dibaca dalam tulisan E. Netscher dalam bukunya De Nederlanders in Djohor en Siak 1602 tot 1865 . Batavia :Bruning\& Wijt, 1870. 
Muhammad lqbal Anwar, Perkawinan Sosio - Politis Orang Melayu

shadow of a legal excuse for the partition of his empire. He had married four wives, one the Engku Puan

\section{Interpretasi Terhadap Pulau Penyengat Sebagai Mahar} Perkawinan bagi Engku Puteri Raja Hamidah dari Sultan Mahmud Syah III

Pulau Penyengat Indera Sakti dikatakan dalam cerita pusaka yang diterima turun temurun secara lisan atau dari mulut ke mulut bagi masyarakat Melayu Kepulauan adalah sebagai pulau emas kawin atau mahar yang diberikan oleh Sultan Mahmud Syah III Marhum Besar kepada Engku Puteri Raja Hamidah binti Raja Haji Fisabilillah. Kisah cerita ini meskipun tidak tercatat dalam sejarah nasional RI akan tetapi kisah ini sangat kuat melekat pada masyarakat yang berada di sekitar pulau ini

Pulau Penyengat adalah salah satu di antara pulau yang banyak bertebaran di wilayah Kepulauan Riau yang juga dikenal sebagai "Pulau Segantang Lada". ${ }^{26}$ Untuk mencapainya, pulau yang berhadapan dengan kota Tanjung Pinang ini cukup ditempuh dengan memakai motor boat selama sepuluh menit saja. Pulau ini terletak berhadapan dengan kuala Sungai Riau yang berjarah $6 \mathrm{~km}$ dari kota Tanjung Pinang, ibukota dari Provinsi Kepulauan Riau. Pulau ini berukuran kurang lebih hanya 2.500 × 750 m dan berjarak lebih kurang $35 \mathrm{~km}$ dari pulau Batam. Meskipun kecil, pulau ini banyak mengandungi peristiwa sejarah Kerajaan Melayu terutama ketika Kerajaan Melayu belum terpecah menjadi dua yakni (1) tanah Semenanjung dan Singapura menjadi daerah pengaruh Inggris sedangkan (2) Kepulauan Riau dan Lingga menjadi daerah pengaruh Belanda.

Dikarenakan pulau ini hanya sebagai kubu pertahanan saja, maka pulau ini tidak menjadi perhatian penguasa waktu itu kecuali jika terjadi peperangan. Pulau ini dinamakan Penyengat dikarenakan binatang yang bernama Penyengat sangat banyak hidup di pulau ini. Penyengat adalah binatang sejenis lebah yang memiliki bisa atau racun ganas yang dapat mematikan siapa saja yang digigitnya. Dulu, binatang ini selalu menggigit para pelaut yang singgah di pulau ini untuk mengambil air tawar sebagai bekal di laut. Menurut penuturan orang tua-tua dan tokoh masyarakat di sana sekali peristiwa pelaut-pelaut yang datang mengambil air itu diserang oleh binatang yang bernama Penyengat hingga menimbulkan korban jiwa, sejak itu, binatang Penyengat tersebut dianggap sakti, semenjak itu pula masyarakat menyebut pulau ini dengan Pulau Penyengat hingga sekarang meskipun Penyengatnya sudah tidak ada lagi namun nama pulau ini tetap melekat di hati masyarakat dengan sebutan Pulau Penyengat Indera Sakti.

\footnotetext{
26 Baca A. Samad Ahmad, 1985, Kerajaan Johor-Riau, Kuala Lumpur : Dewan Bahasa dan Pustaka Malaysia, pada bagian Pendahuluan hal. vii-xv memberikan gambaran yang jelas mengenai kepentingan Kepulauan Riau sebagai salah satu pusat kerajaan dan kegiatan politik Melayu sejak zaman Sang Nila Utama dan Demang Lebar Daun.
} 
Al-Fikra: Jurnal IImiah Keislaman, Vol.14, No.2, Juli - Desember 2015

Raja Haji Fisabilillah ayahanda Raja Hamidah Engku Puteri selalu menjadikan pulau Penyengat ini sebagai kubu pertahanan ketika perang Riau melawan Belanda. Selama berkecamuknya peperangan antara Kerajaan Riau dengan Belanda mulai sekitar 1782 sampai 1794, maka di pulau ini terjadi peperangan siang dan malam demi membela bangsa dan tanah air dari kolonial penjajah. Apabila perang sedang terjadi, maka pulau ini ramai oleh dentuman bunyi-bunyian dari dalam benteng pertahanan yang dikemas sedemikian rupa. Apabila perang usai pulau ini kembali sepi bagai tak berpenghuni sehingga tidak kelihatan tanda-tanda kehidupan di sana. Memang kenyataannya demikian karena begitu perang selesai, maka para pasukan kembali ke kediamannya masing-masing dan pulau ini kembali membisu tanpa ada yang menyentuhnya. Raja Haji Fisabilillah mendirikan kubu- kubu pertahanan di Pulau Penyengat, yakni di Bukit Penggawa, Bukit Tengah, dan Bukit Kursi. Benteng-benteng ini dilengkapi pula dengan meriam-meriam dalam berbagai ukuran.

Di zaman pemerintahan Sultan Mahmud Syah III (1761-1812) barulah pulau Penyengat mendapat perhatian setelah berlangsung perkawinan antara Raja Hamidah dengan Sultan Mahmud Syah III, karena pulau Penyengat ini dijadikan tempat kediaman bagi isteri keempat Sultan. Kemudian pulau Penyengat ini berubah fungsi dan kegunaannya. Semula sebagai kubu pertahanan saja lalu menjadi tempat tinggal isteri sultan. Tentunya isteri sultan tidak sendirian bermastutin di pulau ini namun disertai oleh masyarakat pendukungnya. Oleh karena itu, semenjak Raja Hamidah binti Raja Haji Fisabilillah menjadi penghuni pulau ini, dapat dikatakan bermulanya sebuah kehidupan bermasyarakat yang mempunyai pemimpin. Di samping itu juga, Sultan Mahmud Syah III menyerahkan pulau ini kepada permaisurinya Raja Hamidah Engku Puteri sebagai mahar atau maskawinnya.

Semenjak itulah pada awal abad ke-19 yakni pada tahun 1803 pulau ini menjadi tempat tinggal manusia yaitu setelah kepemilikannya diserahkan kepada Raja Hamidah sebagai Engku Puteri dari sultan Mahmud Syah III dan kemudian menjadi tempat kedudukan resmi atau pusat pemerintahan Yang Dipertuan Muda yakni Yang Dipertuan Muda Raja Jakfar yang merupakan Yang Dipertuan Muda pertama yang memakai Pulau Penyengat sebagai posnya. la menjadikan pulau mungil itu tempat kedudukannya. Adiknya Raja Ahmad ikut tinggal di situ mendampingi abangnya dalam pekerjaan pemerintahan. Sementara Raja Idris sengaja bertempat tinggal di seberang pulau itu pada tempat yang bernama Senggarang.

Kepemilikan Pulau Penyengat mengalami proses resmi artinya pulau tersebut diserahkan oleh Sultan Mahmud Syah III ketika menyunting Raja Hamidah menjadi isterinya. Pulau Penyengat menjadi mahar perkawinan Sultan Mahmud Syah III. Oleh karena itu, Engku Puteri Raja Hamidah dapat dikatakan sebagai pemilik pulau tersebut. Dan setelah menikah pulau 
Muhammad Iqbal Anwar, Perkawinan Sosio - Politis Orang Melayu

tersebut dijadikan sebagai tempat tinggal Engku Puteri dengan Sultan Mahmud Syah III.

Pada masa dahulu, di tanah Melayu sudah menjadi kebiasaan dalam hal mahar perkawinan dalam bentuk benda keras seperti memberikan sebuah kebun, ladang, sawah dan lain sebagainya kepada calon isteri. Apalagi yang akan menikah itu adalah orang-orang yang terpandang umpamanya kepala suku, keturunan raja atau datuk. Kebiasaan tersebut sudah merata di masyarakat Melayu nusantara tanpa ada faktor perbedaan. Oleh karena itu, terjadinya peristiwa yang dialami oleh Engku Puteri Raja Hamidah yakni mas kawin yang diterimanya dari Sultan Mahmud Syah III dalam bentuk sebuah pulau, merupakan hal yang biasa terjadi dan bukan hal yang baru. Namun untuk masa sekarang, peristiwa tersebut tidak ada lagi di lakukan orang karena mas kawin atau mahar diwujudkan dalam bentuk benda yang mudah di dapat seperti al-Qur'an, perlengkapan shalat, cincin dan uang tunai.

Mengenai perkawinan Raja Hamidah dengan Sultan Mahmud Syah III dapat disimak dalam Tuhfat an-Nafis ${ }^{27}$ yang mencatatkan sebagai berikut.

Syahdan kata sahibul hikayat apabila Engku Othman ayah saudara Engku Muda itu mendengar titah baginda itu, maka segera lah ia mendekati keduanya, iaitu lalulah ditarekkannya tangan kedua dipertemukannya kepada keduanya, bersalam-salaman, berpelok, bercium. Bertangisanlah keduanya, bermaafan. Maka keduanya dihadapan baginda Yang Dipertuan Besar Sultan Mahmud serta raja-raja sekalian adanya. Kemudian baharulah membuat sumpah setia marhum mangkat di kota. Maka apabila selesailah daripada berdamai dan bersumpah setia itu, maka bertitahlah baginda kepada Yang Dipertuan Muda dan kepada Engku Muda dan kepada Engku Busu dan anak raja-raja sekalian titahnya: "Ke Riau lah kita" maka jawab sekaliannya" Silakanlah tuanku" maka bagindapun berangkatlah ke Riau diiringkan sekalian raja-raja itu. Maka apabila tiba ke Riau, baginda Sultan Mahmud pun dinikahkanlah oleh Yang Dipertuan Muda dengan paduka anakanda Raja Hamidah iaitulah Engku Puteri, puteri marhum Raja Haji Fisabilillah.

\footnotetext{
${ }^{27}$ Sampai saat ini barulah empat manuskrip Tuhfat al- Nafis yang dijumpai dan digolongkan ke dalam dua jenis yaitu versi panjang dan versi lebih pendek. Hanya satu manuskrip versi pendek yang ditulis pada tahun 1896 sebagai hadiah kenang-kenangan kepada A. L. van Hasselt seorang Residen Belanda di Riau. Kemudian pada tahun 1903 van Hasselt menghadiahkan manuskrip ini kepada Koninklijk Instituut voor Taal- Land en Volkenkunde di Leiden.

Dalam penelitian ini digunakan manuskrip versi panjang milik Sir Richard Winstedt yang telah diterbitkan dalam J ournal of the Malayan Branch of the Royal Aciatic Society jilid $X$ bagian 2 tahun 1932. Baca hlm. 427.
} 
Al-Fikra: Jurnal IImiah Keislaman, Vol.14, No.2, Juli - Desember 2015

Syahdan setelah selesailah daripada bernikah kahwin maka lalulah memperbuat istana di Tanjung Ungkat, maka tetaplah baginda Sultan Mahmud itu di dalam negeri Riau bersuka-sukaan sehari- hari adanya.

Pada episode lain yakni halaman 255 dituliskan pula sebagai berikut.

Syahdan adapun baginda Sultan Mahmud apabila sudah paduka anakanda baginda itu keduanya balik masing-masing ke negerinya maka baginda pun menyuruh Punggawa Bakak menebas pulau Penyengat Indera Sakti itu dicucikan, karena Punggawa Bakak itu memang duduk di Penyengat itu dan ada empat lima buah rumah. Maka dikerjakan oleh Punggawa Bakak itu seperti titah baginda itu. Maka setelah pulau Penyengat itu ditebas maka baginda pun berbuatlah istana dan kota paritnya dengan mesjid dan balairungnya. Adalah yang memerintahkan segala pekerjaan itu ialah Encik Kalok bin Encik Sulah peranakan Bugis. Maka tiada berapa lamanya selesailah pekerjaan itu. Maka apabila selesai pulau Penyengat itu menjadi negeri tempat kerajaan, maka baginda pun memindahkan paduka adinda Engku Puteri yaitu Raja Hamidah isterinya ke istana pulau Penyengat dengan raja-raja dan orang baik-baiknya sekalian sertanya.

Pada halaman 239 dituliskan sebagai berikut.

Syahdan kata sahibul hikayat sekali peristiwa pada suatu masa maka bertitah baginda Sultan Mahmud kepada paduka dinda baginda Engku Puteri dihadapan anak raja-raja seperti Raja Mahmud putra Tengku Panglima Besar, putera baginda Sulaiman Badrul Alamsyah dan lainnya. Demikian bunyi titahnya: Hai Raja Hamidah, adalah saya membuat pulau P enyengat ini dijadikan negeri sudah cukup dengan istananya serta dengan kota-paritnya. Maka Raja Hamidah lah yang saya buatkan dan jadi miliklah kepada Raja Hamidah.

Syahdan lagi daripada fasal negeri Riau ini daripada hasil-hasil dan lain-lainnya yaitu jadi milik makanan Raja Hamidah adik beradik yaitu segala anak-anak Raja Haji al- Marhum Fisabilillah. Maka tiadalah saya campur lagi barang suatunya. Adapun negeri Lingga maka yaitu bahagian si Komeng lah yaitu putera Raja Jum'at Tengku Abd ar-Rahman dan janganlah Raja Hamidah adik beradik campur lagi daripada hasil-hasilnya dan kharajatnya.

Syahdan kata ahli al-rawi inilah permulaan berbahagi makanan antara kedua pihak Yang Dipertuan Besar pada pekerjaan hasil-hasil dan kharajatnya. Sebermula adalah pekerjaan ini di dalam tahun hijrat sanat 1218 pada tahun J im yaitu pada dua hari bulan Zulkaedah hari Sabtu sudah lepas membuat istana adanya.

Apabila dicermati tek-teks yang tertulis di dalam Tuhfat an- Nafis di atas, maka akan diperoleh kandungan isi yang sarat dengan makna, baik secara harfiah maupun secara maknawi. Secara harfiah dituliskan dengan jelas bahwa Sultan Mahmud Syah mendirikan istana untuk tempat tinggal 
Muhammad lqbal Anwar, Perkawinan Sosio - Politis Orang Melayu

dengan segala kelengkapannya kemudian menyerahkan atau menjadikan pulau Penyengat kepunyaan Raja Hamidah. Perhatikan kalimat berikut.

Hai Raja Hamidah, adalah saya membuat pulau Penyengat ini dijadikan negeri sudah cukup dengan istananya serta dengan kota-paritnya. Maka Raja Hamidah lah yang saya buatkan dan jadi miliklah kepada Raja Hamidah.

Secara maknawi, pada kalimat tersebut dilakukan interpretasi verbal melalui pendekatan hermeneutik, artinya analisis dilakukan terhadap katakata yang tertulis di dalam kalimat itu secara keseluruhan. Dalam Kamus Besar Bahasa Indonesia (2005:168) buatkan sama dengan membuat yang mengandung arti menjadikan, membikin. Demikian juga dalam Kamus Dewan (2005:209) buatkan sama dengan membuat yang mengandung arti (1) untuk; (2) dijadikan sebagai; (3) membikin. Sedangkan kata milik dalam Kamus Besar Bahasa Indonesia (2005: 744) mengandung arti (1) kepunyaan; (2) hak. Dalam Kamus Dewan (2005:1032)milik berarti kepunyaan; hak. Dalam konteks kalimat ini mengandung arti bahwa Sultan Mahmud memberikan pulau Penyengat kepada Raja Hamidah setelah istana dengan segala kelengkapannya selesai dibuat. Pemberian yang dilakukan Sultan Mahmud ini terjadi ketika Raja Hamidah akan dijadikan isterinya. Apakah pemberian ini dikatakan sebagai sebuah mas kawin (mahar) atau pemberian lainnya ataupun dikatakan pemberian tanpa alasan. Sebenarnya sangat tidak masuk akal rasanya apabila sebuah pemberian seorang sultan kepada seorang perempuan tanpa ada alasan. Dalam hal ini pulau Penyengat dengan segala isinya diserahkan kepada Raja Hamidah untuk didiami dan disebutkan pula bahwa Raja Hamidah lah pemiliknya.

Pada masa dahulu di tanah Melayu selalu terjadi pemberian hadiah kepada seseorang yang dianggap berjasa atau seseorang yang berkepentingan misalnya ketika Raja Sulaiman putera Sultan Abdul Jalil Riayat Syah IV yang bersekutu dengan Bugis menyerang Raja Kecik. Setelah peperangan dimenangkan oleh pihak Raja Sulaiman, lalu wilayah kerajaan Johor dibagi menjadi tiga bagian. Sepertiganya yakni daerah Selangor, Kelang dan Linggi di bawah Daeng Marewah dan Daeng Manompok. Daerah yang disebutkan itu merupakan hadiah Raja Sulaiman kepada Bugis yang telah membantunya dalam merebut kerajaan Johor.

Sementara itu Sultan Mahmud Syah III memberikan pulau Penyengat kepada Raja Hamidah sebagai hadiah perkawinannya. Pemberian pulau Penyengat ini jika dihubungkaitkan dengan peristiwa yang sedang berlangsung yakni perkawinan tentunya konotasi akan mengarah kepada mas kawin atau disebut juga dengan mahar karena sesuatu yang diberikan seorang laki-laki kepada seorang perempuan ketika berlangsungnya perkawinan adalah disebut dengan mas kawin atau mahar. Dalam Kamus Besar Bahasa Indonesia (2005: 696) mahar mengandung arti pemberian 
Al-Fikra: Jurnal IImiah Keislaman, Vol.14, No.2, Juli - Desember 2015

wajib berupa uang atau barang dari mempelai laki-laki kepada mempelai perempuan ketika dilangsungkan akad nikah. Mahar dapat juga diartikan dengan maskawin. Pada perkara ini mahar perkawinan berupa pulau Penyengat.

Masih dalam konteks yang sama, Sultan Mahmud, Engku Puteri dan pulau Penyengat dalam A Hsitory of J ohor ${ }^{28}$ dituliskan bahwa:

1. ... In 1803 Sultan Mahmud married yet a fourth wife,Tengku Hamidah, daughter of the famous Raja Haji, the Yamtuan Muda of Riau who was killed at Teluk Ketapang fighting the Dutch in Malacca. This consort bore Sultan Mahmud a daufter who lived only an hour, but best know as Tengku Puteri, Tengku Hamidah survived Sultan Mahmud, and stayed on his palace at Pulau Penyengat, enjoying the revenue islands and being left in possession of the regalia ...

2. . . . but such a cry might have any meaning and Tengku Puteri Hamidah, sister of the Yamtuan Muda, who should have known her dead consort's wishes, took the order side and refused to give up the regalia until 1822 the Dutch forced their surrender . . .

\section{Kesimpulan}

Pada akhir dari laporan hasil penelitian ini akan disampaikan kesimpulannya.

1. Engku Puteri Raja Hamidah adalah anak perempuan Raja Haji Fisabilillah dari isterinya yang gahara Riau yaitu Raja Perak binti Yang Dipertuan Muda Riau III Daeng Kamboja.

2. Engku Puteri Raja Hamidah binti Raja Haji Fisabilillah kemudian menjadi isteri Sultan Mahmud Syah III yang dikenal dengan sebutan Marhum Besar atau Marhum Mesjid dengan mahar perkawinan berupa pulau Penyengat.

3. Pulau Penyengat dijadikan sebagai mas kawin dimaksudkan untuk merubah fungsi yang semula hanya sebagai kubu pertahanan perang saja kemudian menjadi tempat tinggal Sultan Mahmud dengan Engku Puteri Raja Hamidah beserta rakyatnya kemudian menjadi tempat kedudukan resmi atau pusat pemerintahan Yang Dipertuan Muda yakni Yang Dipertuan Muda Raja Jakfar yang merupakan Yang Dipertuan Muda pertama yang memakai pulau Penyengat sebagai posnya.

4. Pulau Penyengat adalah milik Engku Puteri Raja Hamidah. Hal ini dapat dibuktikan dengan data sejarah yang tergolong tradisional yakni manuskrip

\footnotetext{
${ }^{28} \mathrm{~A}$ History of J ohor adalah tulisan R.O. Winstedt yang telah dipublikasikan dalam JMBRAS pada tahun 1932. Kutipan pertama halaman 73 dan kutipan kedua pada halaman 74 .
} 
Melayu seperti Tuhfat an- Nafis. Demikian juga kepemilikan pulau Penyengat tercantum dalam tulisan kolonial yang hidup pada masanya yakni Elisa Netscher.

5. Engku Puteri Raja Hamidah adalah pemegang regalia kebesaran kerajaan Riau sampai akhir hayatnya. Regalia kerajaan dipertahankannya meskipun pihak Inggris mencoba membayar kepada Engku Puteri dengan uang sejumlah 50.000 ringgit Spanyol ketika itu, namun sikap Inggris tersebut dianggap sebagai penghinaan baginya sebagai pemegang regalia kerajaan.

\section{Daftar Kepustakaan}

Abdullah, Taufik. 2001. Nasionalisme dan Sejarah. Bandung : Satya Historika. -1985. Beberapa Aspek Penelitian Sejarah Lokal, Yogyakarta : Lembaga Reset dan Survei IAIN Suka.

------.dan Abdurrahman Surjomohardjo. 1985. IImu Sejarah dan Historiografi : Arah dan Perspektif. Jakarta : Gramedia.

Adil, H. Buyung. 1971. Sejarah J ohor. Kuala Lumpur: Dewan Bahasa dan Pustaka Malaysia.

Ahmad, A. Samad. 1985, Kerajaan J ohor-Riau.Kuala Lumpur : Dewan Bahasa dan Pustaka Malaysia,

Tim Penyusun. 2006. Biro Pusat Statistik Provinsi Kepulauan Riau. Tanjungpinang : Pemerintah Daerah Tingkat I.

Carr, Edward Hellet. 1961. What is history. Terj. Abdur Rahman Haji Ismail. Kuala Lumpur : Dewan Bahasa dan Pustaka Malaysia.

Deraman, A. Azis. 2003. Masyarakat dan kebudayaan Malaysia, ed. baharu.

Endraswara, Suwardi. 2006. Metode, teori, teknik penelitian budaya.Yogyakarta : Pustaka Widyatama.

Freek Colombijn. 1997. "Een Milliu - effect rapportage van de gambircultuur in de Riau artchipel in de negentiende eeuw." Tijdschrift voor Geschiedenis. 110.

Gani, Ruslan Abdul. 1981. Pengantar Ilmu Sejarah. Jakarta : Prapanca.

Garraghan, Gilbert J. 1963. A guide to historical metod. New York : Fordham University Press.

Gazalba, Sidi. 1981. Pengantarlilmu Sejarah . Jakarta : Bulan Bintang

Gottschalk, Louis. 1985. Mengerti Sejarah. Terj. Nugroho Notosusanto. Jakarta : UI Press

Hamidi, UU. 1999. Islam dan Masyarakat Melayu di Riau. Pekanbaru : UIR Press. 
Al-Fikra: Jurnal IImiah Keislaman, Vol.14, No.2 , Juli - Desember 2015

Hamka. 1981. Sejarah Umat Islam. Jil. IV, cetakan ketiga. Jakarta : Bulan Bintang.

Hall, D. G. E. 1971. The History of South Asia. Kuala Lumpur : Dewan Bahasa dan Pustaka Malaysia.

Haji, Raja Ali. 1965. Tuhfat al- Nafis. Singapura : Malaysia Publications Ltd.

Harry J. Marks. 1959. The First Contest For Singapura 1819-1824. Gravenhage- Martinus Nijhoff.

Hussein, Ismail. 1992. Tamadun Melayu. Kuala Lumpur : Dewan Bahasa dan Pustaka Malaysia.

Hashim, Mohd.Yusof. 1992. Pensejarahan Melayu:Kajian tentang tradisi sejarah Melayu nusantara. Kuala Lumpur: Dewan Bahasa dan Pustaka Malaysia.

Ibrahim, Muhd. Yusof. 1991. Ilmu sejarah : pengertian, falsafah dan kaedah.Kuala Lumpur : Dewan Bahasa dan Pustaka Malaysia.

Junus, Umar, 1989. Fiksyen dan Sejarah Suatu Dialog. Kuala Lumpur : Dewan Bahasa dan Pustaka Kementerian Pendidikan Malaysia.

Kartodirjo, Sartono. 1982. Pemikiran dan Perkembangan Historiografi Indonesia Suatu Alternatif . Jakarta : Gramedia.

-------. 1992. Pendekatan IImu Sosial dalam Metodologi Sejarah. Jakarta : Gramedia.

Koentjaraningrat. 1994. Kebudayaan Mentalitas dan Pembangunan. Jakarta : Gramedia.

Kuntowijoyo. 1993. Metodologi Sejarah. Yogyakarta : P.T. Tiara Wacana.

Lutfi, Muchtar. et. al. 1977. Sejarah Riau. Pekanbaru : Percetakan Riau.

Marsden, William. 1966. The History of Sumatra. Kuala Lumpur: Oxford University Press.

Matheson, Virginia. (ed).1982. Tuhfat al-Nafis. Petaling Jaya : Fajar Bakti Sdn. Bhd.

Netsher, E . 1854. ' Beschrijving van een gedeelte der residentie Riaouw', dalam TBG. II.

Piah, Harun Mat. 1989. "Tamadun Melayu Sebagai Asas Kebudayaan Kebangsaan: Suatu Tinjauan dan Justifikasi" dalam Ismail Hussein. Tamadun Melayu. Jilid 2. Kuala Lumpur : Dewan Bahasa dan Pustaka Malaysia.

Reinoust, Vos. 1993. Gentle J anus, Merchant Prince: The VOC and the tightrope of diplomacy in the Malay world 1740 - 1800. Leiden : KITLV Press.

Suparlan, Parsudi. 1995. Orang Sakai di Riau (Masyarakat Terasing dalam Masyarakat Indonesia). Jakarta : Yayasan Obor Indonesia. 
Muhammad lqbal Anwar, Perkawinan Sosio - Politis Orang Melayu

Shellabear, W. G. (ed). 1954. Sejarah Melayu or the Malay Annals. Singapura : The Malaya Publishing House Ltd.

------. 1967. Sejarah Melayu. Kuala Lumpur : Oxford University Press.

Tamim, H. Wan Saleh. 1984. Sejarah Hancurnya Singgasana Melayu I dan Timbulnya Ssinggasana Melayu II. Pekanbaru : Pemerintah Daerah Riau.

Thamrin, Husni. 2007. Etnografi Melayu Tradisi dan Modernisasi. Pekanbaru : SUSKA Press.

Taylor, Robert B. 1986. Cultural Ways a Concise Introduction to Cultural Anthropology. Waveland Press.

Tim Penyusun. 1977/1978. Sejarah Daerah Riau. Pekanbaru : Departemenn Pendidikan dan Kebudayaan.

Winstedt, R. O. 1982. A History of Malaya. Kuala Lumpur \& Singapura : Merican \& Sons (Malaysia) Sdn. Bhd.

\section{Kamus}

A. Merriem-Webster. 1967. Webster's Seventh New Collegiate Dictionary, Toronto:Thomas Allen \& Son Limited.

Tim Penyusun. 2005. Kamus Besar Bahasa Indonesia. Edisi Ketiga. Jakarta : Balai Pustaka.

Tim Penyusun. 2005. Kamus Dewan. Edisi Keempat. Kuala Lumpur : Dewan Bahasa dan Pustaka Malaysia.

\section{Arsib dan Manuskrip}

E. Netscher. 1870. De Nederlanders in Djohor en Siak 1602 - 1865. Batavia : Bruining \& Wijt.

Raja Ali Haji. 1932. Tuhfat al- Nafis. Singapura : Malaysia Publications Ltd.

R.O. Winstedt. 1932. A History of J ohor (1364-1895). JMBRAS. Desember 1932.

Surat-surat Perjanjian antara Kesultanan Riau dengan Pemerintahan V. O. C dan Hindia-Belanda 1784-1909.

Virginia Matheson. (ed).1982. Tuhfat al-Nafis. Petaling Jaya : Fajar Bakti Sdn. Bhd.

Ranzaow, LC Van, “ Korte Geneologi der vorstelijk familie van het rijk van Djohor ... April 1827." KITLV, Leiden. 